\title{
A satellite data driven biophysical modeling approach for estimating northern peatland and tundra $\mathrm{CO}_{2}$ and $\mathrm{CH}_{4}$ fluxes
}

\author{
J. D. Watts ${ }^{1,2}$, J. S. Kimball ${ }^{1,2}$, F. J. W. Parmentier ${ }^{3}$, T. Sachs ${ }^{4}$, J. Rinne ${ }^{5}$, D. Zona ${ }^{6,7}$, W. Oechel ${ }^{7}$, T. Tagesson ${ }^{8}$, \\ M. Jackowicz-Korczyński ${ }^{3}$, and M. Aurela ${ }^{9}$ \\ ${ }^{1}$ Flathead Lake Biological Station, The University of Montana, 32125 Bio Station Lane, Polson, MT, USA \\ ${ }^{2}$ Numerical Terradynamic Simulation Group, CHCB 428, 32 Campus Drive, The University of Montana, Missoula, MT, USA \\ ${ }^{3}$ Department of Physical Geography and Ecosystem Science, Lund University, Sölvegatan 12, 223 62, Lund, Sweden \\ ${ }^{4}$ Helmholtz Centre Potsdam - GFZ German Research Centre for Geosciences, Telegrafenberg, 14473 Potsdam, Germany \\ ${ }^{5}$ Department of Geosciences and Geography; Department of Physics, P.O. Box 64, 00014 University of Helsinki, Finland \\ ${ }^{6}$ Department of Animal and Plant Science, University of Sheffield, Sheffield, UK \\ ${ }^{7}$ Department of Biology, San Diego State University, San Diego, CA, USA \\ ${ }^{8}$ Department of Geography and Geology, Copenhagen University, Øster Voldgade 10, 1350 Copenhagen, Denmark \\ ${ }^{9}$ Finnish Meteorological Institute, Climate Change Research, P.O. Box 503, 00101, Helsinki, Finland
}

Correspondence to: J. D. Watts (jennifer.watts@ntsg.umt.edu)

Received: 5 September 2013 - Published in Biogeosciences Discuss.: 25 October 2013

Revised: 25 February 2014 - Accepted: 26 February 2014 - Published: 9 April 2014

\begin{abstract}
The northern terrestrial net ecosystem carbon balance (NECB) is contingent on inputs from vegetation gross primary productivity (GPP) to offset the ecosystem respiration $\left(R_{\text {eco }}\right)$ of carbon dioxide $\left(\mathrm{CO}_{2}\right)$ and methane $\left(\mathrm{CH}_{4}\right)$ emissions, but an effective framework to monitor the regional Arctic NECB is lacking. We modified a terrestrial carbon flux (TCF) model developed for satellite remote sensing applications to evaluate wetland $\mathrm{CO}_{2}$ and $\mathrm{CH}_{4}$ fluxes over pan-Arctic eddy covariance (EC) flux tower sites. The TCF model estimates GPP, $\mathrm{CO}_{2}$ and $\mathrm{CH}_{4}$ emissions using in situ or remote sensing and reanalysis-based climate data as inputs. The TCF model simulations using in situ data explained $>70 \%$ of the $r^{2}$ variability in the 8 day cumulative EC measured fluxes. Model simulations using coarser satellite (MODIS) and reanalysis (MERRA) records accounted for approximately $69 \%$ and $75 \%$ of the respective $r^{2}$ variability in the tower $\mathrm{CO}_{2}$ and $\mathrm{CH}_{4}$ records, with corresponding RMSE uncertainties of $\leq 1.3 \mathrm{~g} \mathrm{C} \mathrm{m}^{-2} \mathrm{~d}^{-1}\left(\mathrm{CO}_{2}\right)$ and $18.2 \mathrm{mg} \mathrm{C} \mathrm{m}^{-2} \mathrm{~d}^{-1}\left(\mathrm{CH}_{4}\right)$. Although the estimated annual $\mathrm{CH}_{4}$ emissions were small $\left(<18 \mathrm{~g} \mathrm{C} \mathrm{m}^{-2} \mathrm{yr}^{-1}\right)$ relative to $R_{\text {eco }}\left(>180 \mathrm{~g} \mathrm{C} \mathrm{m}^{-2} \mathrm{yr}^{-1}\right)$, they reduced the across-site NECB by $23 \%$ and contributed to a global warming potential of approximately $165 \pm 128 \mathrm{~g} \mathrm{CO}_{2} \mathrm{eq} \mathrm{m}^{-2} \mathrm{yr}^{-1}$ when considered over a 100 year time span. This model evaluation indi-
\end{abstract}

cates a strong potential for using the TCF model approach to document landscape-scale variability in $\mathrm{CO}_{2}$ and $\mathrm{CH}_{4}$ fluxes, and to estimate the NECB for northern peatland and tundra ecosystems.

\section{Introduction}

Northern peatland and tundra ecosystems are important components of the terrestrial carbon cycle and store over half of the global soil organic carbon reservoir in seasonally frozen and permafrost soils (Hugelius et al., 2013). However, these systems are becoming increasingly vulnerable to carbon losses as $\mathrm{CO}_{2}$ and $\mathrm{CH}_{4}$ emissions, resulting from climate warming and changes in the terrestrial water balance (Kane et al., 2012; Kim et al., 2012) that can increase soil carbon decomposition. Recent net $\mathrm{CO}_{2}$ exchange in northern tundra and peatland ecosystems varies from a sink of $291 \mathrm{Tg} \mathrm{C} \mathrm{yr}^{-1}$ to a source of $80 \mathrm{Tg} \mathrm{Cyr}^{-1}$, when considering the substantial uncertainty in regional estimates using scaled flux observations, atmospheric inversions, and ecosystem process models (McGuire et al., 2012). The magnitude of a carbon sink largely depends on the balance between carbon uptake by vegetation productivity and losses from 
soil mineralization and respiration processes. High-latitude warming can increase ecosystem carbon uptake by reducing cold-temperature constraints on plant carbon assimilation and growth (Hudson et al., 2011; Elmendorf et al., 2012). Soil warming also accelerates carbon losses due to the exponential effects of temperature on soil respiration, whereas wet and inundated conditions shift microbial activity towards anaerobic consumption pathways that are relatively slow but can result in substantial $\mathrm{CH}_{4}$ production (Moosavi and Crill, 1997; Merbold et al., 2009). Regional wetting across the Arctic (Watts et al., 2012; Zhang et al., 2012a) may increase $\mathrm{CH}_{4}$ emissions, which have a radiative warming potential at least 25 times more potent than $\mathrm{CO}_{2}$ per unit mass over a 100 year time horizon (Boucher et al., 2009). The northern latitudes already contain over $50 \%$ of global wetlands and recent increases in atmospheric $\mathrm{CH}_{4}$ concentrations have been attributed to heightened gas emissions in these areas during periods of warming (Dlugokencky et al., 2009; Dolman et al., 2010). Northern peatland and tundra $\left(\geq 50^{\circ} \mathrm{N}\right)$ reportedly contribute between 8 and $79 \mathrm{TgC}$ in $\mathrm{CH}_{4}$ emissions each year, but these fluxes have been difficult to constrain due to uncertainty in the parameterization of biogeochemical models, the regional characterization of wetland extent and water table depth, and a scarcity of ecosystem-scale $\mathrm{CH}_{4}$ emission observations (Petrescu et al., 2010; Riley et al., 2011; Spahni et al., 2011; McGuire et al., 2012; Meng et al., 2012).

Ecosystem studies using chamber and tower eddy covariance (EC) methods continue to provide direct measurements of $\mathrm{CO}_{2}$ and $\mathrm{CH}_{4}$ fluxes and add valuable insight into the environmental constraints on these processes. However, extrapolating localized carbon fluxes to regional scales has proven difficult and is severely constrained by the limited number of in situ observations and the large spatial extent and heterogeneity of peatland and tundra ecosystems. Recent approaches have used satellite-based land cover classifications, photosynthetic leaf area maps, or wetness indices to "upscale" $\mathrm{CO}_{2}$ (Forbrich et al., 2011; Marushchak et al., 2013) and $\mathrm{CH}_{4}$ (Tagesson et al., 2013; Sturtevant and Oechel, 2013) flux measurements. Remote sensing inputs have also been used in conjunction with biophysical process modeling to estimate landscape-level changes in plant carbon assimilation and soil $\mathrm{CO}_{2}$ emissions (Yuan et al., 2011; Tagesson et al., 2012a; Yi et al., 2013). Previous analyses of regional $\mathrm{CH}_{4}$ contributions have ranged from the relatively simple modification of $\mathrm{CH}_{4}$ emission rate estimates for wetland fractions according to temperature and carbon substrate constraints (Potter et al., 2006; Clark et al., 2011) to the use of more complex multi-layer wetland $\mathrm{CH}_{4}$ models with integrated hydrological components (McGuire et al., 2012; Wania et al., 2013). Yet, most investigations have not examined the potential for simultaneously assessing $\mathrm{CO}_{2}$ and $\mathrm{CH}_{4}$ fluxes, and the corresponding net ecosystem carbon balance (Sitch et al., 2007; McGuire et al., 2012; Olefeldt et al., 2012) for peatland and tundra using a satellite remote sensing-based model approach.
It is well recognized that sub-surface conditions influence the land-atmosphere exchange of $\mathrm{CO}_{2}$ and $\mathrm{CH}_{4}$ production. However, near-surface soil temperature, moisture and carbon substrate availability play a crucial role in regulating ecosystem carbon emissions. Strong associations between surface soil temperature $\left(\leq 10 \mathrm{~cm}\right.$ depth) and $\mathrm{CO}_{2}$ respiration have been observed in Arctic peatland and tundra permafrost systems (Kutzbach et al., 2007). Significant relationships between $\mathrm{CH}_{4}$ emissions and temperature have also been reported (Hargreaves et al., 2001; Zona et al., 2009; Sachs et al., 2010). Although warming generally increases the decomposition of organic carbon, the magnitude of $\mathrm{CO}_{2}$ production is constrained by wet soil conditions (Olivas et al., 2010) that instead favor $\mathrm{CH}_{4}$ emissions and decrease methantrophy in soil and litter layers (Turetsky et al., 2008; Olefeldt et al., 2012). Oxidation by methanotrophic communities in surface soils can reduce $\mathrm{CH}_{4}$ emissions by over $90 \%$ when gas transport occurs through diffusion (Preuss et al., 2013), but this constraint is often minimized when pore water content rises above 55-65 \% (von Fischer and Hedin, 2007; Sjögersten and Wookey, 2009). Despite increases in the availability of organic carbon and accelerated $\mathrm{CO}_{2}$ release due to soil warming and thickening of the active layer in permafrost soils (Dorrepaal et al., 2009), anaerobic communities have shown a preference for light-carbon fractions (e.g., amines, carbonic acids) that are more abundant in the upper soil horizons (Wagner et al., 2009). Similarly, labile carbon substrates from recent photosynthates and root exudates have been observed to increase $\mathrm{CH}_{4}$ production relative to heavier organic carbon fractions (Ström et al., 2003; Dijkstra et al., 2012; Olefeldt et al., 2013) that require longer decomposition pathways to break down complex molecules into the simple compounds (i.e., acetate, $\mathrm{H}_{2}+\mathrm{CO}_{2}$ ) used in methanogenesis (Le Mer and Roger, 2001).

The objective of this study was to evaluate the feasibility of using a satellite remote sensing data driven modeling approach to assess the daily and seasonal variability in $\mathrm{CO}_{2}$ and $\mathrm{CH}_{4}$ fluxes from northern peatland and tundra ecosystems, according to near-surface environmental controls including soil temperature, moisture and available soil organic carbon. In this paper we incorporate a newly developed $\mathrm{CH}_{4}$ emissions algorithm within an existing terrestrial carbon flux (TCF) $\mathrm{CO}_{2}$ model framework (Kimball et al., 2012; Yi et al., 2013). The $\mathrm{CH}_{4}$ emissions algorithm simulates gas production using near-surface temperature, anaerobic soil fractions and labile organic carbon as inputs. Plant $\mathrm{CH}_{4}$ transport is determined by vegetation growth characteristics derived from gross primary production (GPP), plant functional traits and canopy/surface turbulence. Methane diffusion is determined based on temperature and moisture constraints to gas movement through the soil column, and oxidation potential. Ebullition of $\mathrm{CH}_{4}$ is assessed using a simple gradient method (van Huissteden et al., 2006).

The integrated TCF model allows for satellite remote sensing information to be used as primary inputs, requires 
minimal parameterization relative to more complex ecosystem process models, and provides a framework to monitor the terrestrial net ecosystem carbon balance (NECB). Although the NECB also encompasses other mechanisms of carbon transport, including dissolved and volatile organic carbon emissions and fire-based particulates, the NECB is limited in this study to $\mathrm{CO}_{2}$ and $\mathrm{CH}_{4}$ fluxes, which often are primary contributors in high-latitude tundra and peatland ecosystems (McGuire et al., 2010).

To evaluate the combined $\mathrm{CO}_{2}$ and $\mathrm{CH}_{4}$ algorithm approach, we compared TCF model simulations to tower EC records from six northern peatland and tundra sites within North America and Eurasia. For this study, baseline simulations driven with tower EC-based GPP and in situ meteorology data were first used to assess the capability of the TCF model approach to quantify temporal changes in landscapescale carbon $\left(\mathrm{CH}_{4}\right.$ and $\left.\mathrm{CO}_{2}\right)$ fluxes. Secondly, $\mathrm{CO}_{2}$ and $\mathrm{CH}_{4}$ simulations using internal TCF model GPP estimates (Yi et al., 2013) and inputs from satellite and global model reanalysis records were used to evaluate the relative uncertainty introduced when using coarser scale information in place of in situ data. These satellite and reanalysis driven simulations were then used to determine the annual $\mathrm{CO}_{2}$ and $\mathrm{CH}_{4}$ fluxes at the six tower sites, and the relative impact of $\mathrm{CH}_{4}$ emissions on the NECB.

\section{Methods}

\subsection{TCF model description}

The combined TCF model $\mathrm{CO}_{2}$ and $\mathrm{CH}_{4}$ framework regulates carbon gas exchange using soil surface temperature, moisture and soil organic carbon availability as inputs, and has the flexibility to run simulations at local and regional scales. TCF model estimates of ecosystem respiration $\left(R_{\text {eco }}\right)$ and net ecosystem $\mathrm{CO}_{2}$ exchange (NEE) have been evaluated against tower EC data sets from boreal and tundra systems using GPP, surface $\left(\leq 10 \mathrm{~cm}\right.$ depth) soil temperature $\left(T_{\mathrm{s}}\right)$ and volumetric moisture content $(\theta)$ inputs available from global model reanalysis and satellite remote sensing records (Kimball et al., 2009; McGuire et al., 2012). A recent adjustment to the TCF model (Kimball et al., 2012; Yi et al., 2013) incorporates a light-use efficiency (LUE) algorithm that provides internally derived GPP calculations to determine $R_{\text {eco }}$ and NEE fluxes at a daily time step. The adjusted TCF $\mathrm{CO}_{2}$ model also allows for better user control over parameter settings and surface meteorological inputs (Kimball et al., 2012). The $\mathrm{CO}_{2}$ and newly added $\mathrm{CH}_{4}$ flux model components are described in the following sections. A summary of the TCF model inputs, parameters, and the associated parameter values used in this study are provided in the Supplement (tables S1 and S2; Fig. S1).

\subsection{1 $\mathrm{CO}_{2}$ flux component}

The internal TCF model GPP algorithm estimates daily fluxes according to a biome-dependent vegetation maximum LUE coefficient $\left(\varepsilon_{\max } ; \mathrm{mg} \mathrm{CMJ}^{-1}\right)$ that represents the optimal conversion of absorbed solar energy and $\mathrm{CO}_{2}$ to plant organic carbon through photosynthesis (Kimball et al., 2012). To account for daily minimum air temperature $\left(T_{\min }\right)$ and atmospheric vapor pressure deficit (VPD) constraints on photosynthesis (Running et al., 2004), $\varepsilon_{\max }$ is reduced $(\varepsilon)$ using dimensionless linear rate scalars ranging from 0 (total inhibition) to 1 (no inhibition) that are described elsewhere (i.e., Kimball et al., 2012; Yi et al., 2013). In this study we also account for the sensitivity of shallow rooted vegetation and bryophytes, which lack vascular tissues for water transport, to changes in surface volumetric soil water (Wu et al., 2013), where $\theta_{\min }$ and $\theta_{\max }$ are the specified minimum and maximum parameter values:

$$
\begin{aligned}
& \varepsilon=\varepsilon_{\max } \times f(\mathrm{VPD}) \times f\left(T_{\min }\right) \times f(\theta) \\
& \text { where } f(\theta)=\left(\theta-\theta_{\min }\right) /\left(\theta_{\max }-\theta_{\min }\right) . \\
& \text { Simulated GPP }\left(\mathrm{g} \mathrm{C} \mathrm{m}^{-2} \mathrm{~d}^{-1}\right) \text { is obtained as } \\
& \mathrm{GPP}=\varepsilon \times 0.45 \mathrm{SW}_{\mathrm{rad}} \times \mathrm{FPAR},
\end{aligned}
$$

where $\mathrm{SW}_{\text {rad }}\left(\mathrm{W} \mathrm{m}^{-2}\right)$ is incoming shortwave radiation and FPAR is the fraction of daily photosynthetically active solar radiation (PAR; $\mathrm{MJ} \mathrm{m}^{-2}$ ) absorbed by plants during photosynthesis. For this approach, PAR is assumed to be $45 \%$ of $\mathrm{SW}_{\text {rad }}$ (Zhao et al., 2005). Remotely sensed normalized difference vegetation index (NDVI) records have been used to estimate vegetation productivity (Schubert et al., 2010a; Parmentier et al., 2013) and changes in growing season length (Beck and Goetz, 2011) across northern peatland and tundra environments. Daily FPAR is derived using the approach of Badawy et al. (2013) to mitigate potential biases in low biomass landscapes (Peng et al., 2012):

$$
\mathrm{FPAR}=\frac{0.94\left(\text { Index }- \text { Index }_{\min }\right)}{\text { Index }_{\text {range }}} .
$$

This approach uses NDVI or simple ratio (SR; i.e., $(1+\mathrm{NDVI}) /(1-\mathrm{NDVI}))$ indices as input index values. The results are then averaged to obtain FPAR. Index ${ }_{\text {range }}$ corresponds to the difference between the 2nd and 98th percentiles in the NDVI and SR distributions (Badawy et al., 2013).

Biome-specific autotrophic respiration $\left(R_{\mathrm{a}}\right)$ is estimated using a carbon use efficiency (CUE) approach that considers the ratio of net primary production (NPP) to GPP (Choudhury, 2000). Carbon loss from heterotrophic respiration $\left(R_{\mathrm{h}}\right)$ is determined using a three-pool soil litter decomposition scheme consisting of metabolic $\left(C_{\mathrm{met}}\right)$, structural $\left(C_{\mathrm{str}}\right)$ and recalcitrant $\left(C_{\text {rec }}\right)$ organic carbon pools with variable decomposition rates. The $C_{\text {met }}$ pool represents easily decomposable 
plant residue and root exudates including amino acids, sugars and simple polysaccharides, whereas the $C_{\text {str }}$ pool consists of litter residues such as hemi-cellulose and lignin (Ise et al., 2008; Porter et al., 2010). The $C_{\text {rec }}$ pool includes physically and chemically stabilized carbon derived from the $C_{\text {met }}$ and $C_{\text {str }}$ pools and also corresponds to humified peat. A fraction of daily NPP $\left(F_{\mathrm{met}}\right)$ is first allocated as readily decomposable litterfall to $C_{\text {met }}$ and the remaining portion $\left(1-F_{\text {met }}\right)$ is transferred to $C_{\text {str }}$ (Ise and Moorcroft, 2006; Kimball et al., 2009). To account for reduced mineralization in tundra and peatland environments, approximately $70 \%$ of $C_{\mathrm{str}}\left(F_{\mathrm{str}}\right)$ is reallocated to $C_{\text {rec }}$ (Ise and Moorcroft, 2006; Ise et al., 2008):

$\mathrm{d} C_{\text {met }} / \mathrm{d} t=\mathrm{NPP} \times F_{\text {met }}-R_{\mathrm{h} \text {,met }}$

$\mathrm{d} C_{\text {str }} / \mathrm{d} t=\operatorname{NPP}\left(1-F_{\text {met }}\right)-\left(F_{\text {str }} \times C_{\text {str }}\right)-R_{\mathrm{h}, \mathrm{str}}$

$\mathrm{d} C_{\text {rec }} / \mathrm{d} t=\left(F_{\text {str }} \times C_{\text {str }}\right)-R_{\mathrm{h}, \text { rec }}$.

Daily $\mathrm{CO}_{2}$ loss from the $C_{\text {met }}$ pool (i.e., $R_{\mathrm{h} \text {,met }}$ ) is determined as the product of $C_{\text {met }}$ and an optimal decomposition rate parameter $\left(K_{\mathrm{p}}\right)$. The realized decomposition rate $\left(K_{\mathrm{met}}\right)$ results from the attenuation of $K_{\mathrm{p}}$ by dimensionless $T_{\mathrm{s}}$ and $\theta$ multipliers ( $T_{\text {mult }}$ and $W_{\text {mult }}$, respectively), that vary between 0 (fully constrained) and 1 (no constraint):

$$
\begin{aligned}
& K_{\text {met }}=K_{\mathrm{p}} \times T_{\text {mult }} \times W_{\text {mult }} \\
& T_{\text {mult }}=\exp \left[308.56\left(66.02^{-1}-\left(T_{\mathrm{s}}+T_{\text {ref }}-66.17\right)^{-1}\right)\right] \\
& W_{\text {mult }}=1-2.2\left(\theta-\theta_{\text {opt }}\right)^{2}
\end{aligned}
$$

The temperature constraints are imposed using an Arrheniustype function (Lloyd and Taylor, 1994; Kimball et al., 2009) where decomposition is no longer limited when average daily $T_{\mathrm{S}}$ exceeds a user-specified reference temperature $\left(T_{\text {ref }}\right.$; in $\mathrm{K})$ that can vary with carbon substrate complexity, physical protection, oxygen availability and water stress (Davidson and Janssens, 2006). The $W_{\text {mult }}$ modifier accounts for the inhibitory effect of dry and near-saturated soil moisture conditions on heterotrophic decomposition (Oberbauer et al., 1996). For this study, $\theta_{\mathrm{opt}}$ is set to $80 \%$ of pore saturation to account for ecosystem adaptations to wet soil conditions (Ise et al., 2008; Zona et al., 2012) and near-surface oxygen availability provided by plant root transport (Elberling et al., 2011). Decomposition rates for $C_{\text {str }}$ and $C_{\text {rec }}\left(K_{\text {str }}, K_{\text {rec }}\right)$ are determined as $40 \%$ and $1 \%$ of $K_{\text {met }}$, respectively (Kimball et al., 2009), and $R_{\mathrm{h}}$ is the total $\mathrm{CO}_{2}$ loss from the three soil organic carbon pools:

$R_{\mathrm{h}}=K_{\text {met }} \times C_{\text {met }}+K_{\text {str }} \times C_{\text {str }}+K_{\text {rec }} \times C_{\text {rec }}$.

Finally, the TCF model estimates NEE $\left(\mathrm{g} \mathrm{C} \mathrm{m}^{-2} \mathrm{~d}^{-1}\right)$ as the residual difference between $R_{\text {eco }}$, which includes $R_{\mathrm{a}}$ and $R_{\mathrm{h}}$ respiration components, and GPP. Negative (-) and positive (+) NEE fluxes denote respective terrestrial $\mathrm{CO}_{2}$ sink and source activity:

$\mathrm{NEE}=\left(R_{\mathrm{a}}+R_{\mathrm{h}}\right)-$ GPP.

\subsection{2 $\mathrm{CH}_{4}$ flux component}

A $\mathrm{CH}_{4}$ emissions algorithm was incorporated within the TCF model to estimate $\mathrm{CH}_{4}$ fluxes for peatland and tundra landscapes. The model estimates $\mathrm{CH}_{4}$ production according to $T_{\mathrm{s}}, \theta$, and labile carbon availability. Plant $\mathrm{CH}_{4}$ transport is modified by vegetation growth and production, plant functional traits, and canopy aerodynamic conductance that takes into account the influence of wind turbulence on moisture/gas flux between vegetation and the atmosphere. The $\mathrm{CH}_{4}$ module is similar to other process models (e.g., Walter and Heimann, 2000; van Huissteden et al., 2006), but reduces to a one-dimensional near-surface soil profile following Tian et al. (2010) to simplify model parameterization amenable to remote sensing applications. For the purposes of this study, the soil profile is defined for surface $(\leq 10 \mathrm{~cm}$ depth) soil layers as most temperature and moisture retrievals from satellite remote sensing do not characterize deeper soil conditions. Although this approach may not account for variability in carbon fluxes associated with deeper soil constraints, field studies from high-latitude ecosystems have reported strong associations between $\mathrm{CH}_{4}$ emissions and near-surface conditions including $T_{\mathrm{S}}$ and soil moisture (Hargreaves et al., 2001; Sachs et al., 2010; von Fischer et al., 2010; Sturtevant et al., 2012; Tagesson et al., 2012b).

\section{$\mathrm{CH}_{4}$ production}

Soil moisture in the upper rhizosphere is a fundamental control on $\mathrm{CH}_{4}$ production and emissions into the atmosphere. Methanogenesis $\left(R_{\mathrm{CH}_{4}}\right)$ within the saturated soil pore volume $\left(\varphi_{\mathrm{s}} ; \mathrm{m}^{-3}\right.$; the aerated pore volume is denoted as $\left.\varphi_{\mathrm{a}}\right)$ is determined according to an optimal $\mathrm{CH}_{4}$ production rate $\left(R_{\mathrm{o}}\right.$; $\mu \mathrm{MCH}_{4} \mathrm{~d}^{-1}$ ) and labile photosynthates:

$$
R_{\mathrm{CH}_{4}}=\left(R_{\mathrm{O}} \times \phi_{\mathrm{S}}\right) \times C_{\mathrm{met}} \times Q_{10 p}^{\left(T_{\mathrm{S}}-T_{p}\right) / 10} .
$$

For this study, $\mathrm{CH}_{4}$ production was driven using the soil $C_{\text {met }}$ pool to reflect contributions by lower weight carbon substrates (Reiche et al., 2010; Corbett et al., 2013) in labile organic carbon-rich environments. Carbon from the $C_{\text {str }}$ pathway may also be allocated for $\mathrm{CH}_{4}$ production in ecosystems with lower labile organic carbon inputs and higher contributions by hydrogenotrophic methanogenesis (Alstad and Whiticar, 2011). The $Q_{10 p}$ temperature modifier is used as an approximation to the Arrhenius equation and describes the temperature dependence of biological processes (Gedney and Cox, 2003; van Huissteden et al., 2006). The reference temperature $\left(T_{p}\right)$ typically reflects mean annual or non-frozen season climatology. Both $Q_{10 p}$ and $T_{p}$ can be adjusted, in addition to $R_{\mathrm{o}}$, to accommodate varying temperature sensitivities in response to ecosystem differences in substrate quality and other environmental conditions (van Hulzen et al., 1999; Inglett et al., 2012). Methane additions from $R_{\mathrm{CH}_{4}}$ are first allocated to a temporary soil storage pool $\left(C_{\mathrm{CH}_{4}}\right)$ prior to determining the $\mathrm{CH}_{4}$ emissions for each $24 \mathrm{~h}$ time step; $C_{\text {met }}$ 
is also updated to account for carbon losses due to $\mathrm{CH}_{4}$ production.

\section{$\mathrm{CH}_{4}$ emission}

The magnitude of daily $\mathrm{CH}_{4}$ emissions $\left(\mathrm{F}_{\mathrm{CH}_{4}}\right)$ from the soil profile is determined through plant transport $\left(F_{\text {plant }}\right)$, soil diffusion $\left(F_{\text {diff }}\right)$ and ebullition $\left(F_{\text {ebull }}\right)$ pathways:

$F_{\mathrm{CH}_{4}}=F_{\text {plant }}+F_{\text {diff }}+F_{\text {ebull }}$.

Vegetation plays an important role in terrestrial $\mathrm{CH}_{4}$ emissions by allowing for gas transport through the plant structure, avoiding slower diffusion through the soil column and often reducing the degree of $\mathrm{CH}_{4}$ oxidation (Joabsson et al., 1999). Daily $F_{\text {plant }}$ is determined using a rate constant $\left(C_{p}\right)$ modified by vegetation growth and production $\left(f_{\text {grow }}\right)$, and an aerodynamic term $(\lambda)$ and a rate scalar $\left(P_{\text {trans }}\right)$ that account for differences in $\mathrm{CH}_{4}$ transport ability according to plant functional type:

$F_{\text {plant }}=\left(C_{\mathrm{CH}_{4}} \times C_{p} \times f_{\text {grow }} \times \lambda \times P_{\text {trans }}\right)\left(1-P_{\text {ox }}\right)$.

A fraction of $F_{\text {plant }}$ is oxidized $\left(P_{\mathrm{ox}}\right)$ prior to reaching the atmosphere and can be modified according to plant functional characteristics (Frenzel and Rudolph, 1998; Ström et al., 2005; Kip et al., 2010). Plant transport is further reduced under frozen surface conditions to account for pathway obstruction by ice and snow or bending of the plant stem following senescence (Hargreaves et al., 2001; Sun et al., 2012). The magnitude of $f_{\text {grow }}$ is determined as the ratio of daily GPP to its annual maximum and is used to account for seasonal differences in root and above-ground biomass (Chanton, 2005).

Aerodynamic conductance $\left(g_{\mathrm{a}}\right)$ represents the influence of near-surface turbulence on energy/moisture fluxes between vegetation and the atmosphere (Roberts, 2000; Yan et al., 2012) and gas transport within the plant body (Grosse et al., 1996; Sachs et al., 2008; Wegner et al., 2010; Sturtevant et al., 2012):

$g_{\mathrm{a}}=\frac{k^{2} \mu_{m}}{\ln \left[\left(z_{m}-d\right) / z_{\mathrm{om}}\right] \ln \left[\left(z_{m}-d\right) / z_{\mathrm{ov}}\right]}$.

Values for $z_{m}$ and $d$ are the respective anemometer and zero plane displacement heights $(\mathrm{m}) ; z_{\mathrm{om}}$ and $z_{\mathrm{ov}}$ are the corresponding roughness lengths $(\mathrm{m})$ for momentum, heat and vapor transfer. The von Karman constant $(k ; 0.40)$ is a dimensionless constant in the logarithmic wind velocity profile (Högström, 1988), $\mu_{m}$ is average daily wind velocity (m $\left.\mathrm{s}^{-1}\right), d$ is calculated as $2 / 3$ of the vegetation canopy height, $z_{\text {om }}$ is roughly $1 / 8$ of canopy height (Yang and Friedl, 2002), and $z_{\mathrm{ov}}$ is $0.1 z_{\mathrm{om}}$ (Yan et al., 2012). The estimated $g_{\mathrm{a}}$ is then scaled between 0 and 1 to obtain $\lambda$ using a linear function for sites with a lower observed sensitivity to surface turbulence; for environments with a higher sensitivity to surface turbulence, a quadratic approach is used when $\mu_{m}$ exceeds $4 \mathrm{~m} \mathrm{~s}^{-1}$ :

$\lambda=0.0246+0.5091 g_{\mathrm{a}}$

$\lambda=0.0885-\left(3.28 g_{\mathrm{a}}\right)+\left(44.51 g_{\mathrm{a}}^{2}\right), \mu_{m}>4 \mathrm{~m} \mathrm{~s}^{-1}$.

Although this approach focuses on the influence of wind turbulence on plant gas transport within vegetated wetlands, it is also applicable for inundated microsites where increases in surface water mixing can stimulate $\mathrm{CH}_{4}$ degassing (Sachs et al., 2010). In addition, Eq. (15) reflects near-neutral atmospheric stability and adjustments may be necessary to accommodate unstable or stable atmospheric conditions (Raupach, 1998).

The upward diffusion of $\mathrm{CH}_{4}$ within the soil profile is determined using a one-layer approach similar to Tian et al. (2010). The rate of $\mathrm{CH}_{4}$ transport $\left(D_{e} ; \mathrm{m}^{-2} \mathrm{~d}^{-1}\right)$ is considered for both saturated $\left(D_{\text {water }} ; 1.73 \times 10^{-4} \mu \mathrm{MCH}_{4} \mathrm{~d}^{-1}\right)$ and aerated $\left(D_{\text {air }} ; 1.73 \mu \mathrm{MCH}_{4} \mathrm{~d}^{-1}\right)$ soil fractions:

$D_{e}=\left(D_{\text {water }} \times \phi_{\mathrm{s}}\right)\left(D_{\text {air }} \times \phi_{\mathrm{a}}\right)$.

Potential daily transport through diffusion $\left(P_{\text {diff }}\right)$ is estimated as the product of $D_{e}$ and the gradient between $C_{\mathrm{CH}_{4}}$ and the concentration of $\mathrm{CH}_{4}$ in the atmosphere $\left(\mathrm{Air}_{\mathrm{CH}_{4}}\right)$. This is further modified by soil tortuosity $(\tau ; 0.66)$, which increases exponentially for $T_{\mathrm{S}}<274 \mathrm{~K}$ to account for slower gas movement at colder temperatures and barriers to diffusion resulting from near-surface ice formation (Walter and Heimann, 2000; Zhuang et al., 2004), and pathway constraints within the saturated pore fraction $(1-\theta)$ :

$$
\begin{aligned}
& P_{\text {diff }}=\tau \times D_{e}\left(C_{\mathrm{CH}_{4}}-\mathrm{Air}_{\mathrm{CH}_{4}}\right)(1-\theta) \\
& T_{\mathrm{s}} \geq 274, \quad \tau=0.66 \\
& T_{\mathrm{S}}<274, \quad \tau=0.05+10^{-238} \times T_{\mathrm{s}}^{97.2} .
\end{aligned}
$$

A portion of diffused $\mathrm{CH}_{4}$ is oxidized $\left(R_{\mathrm{OX}}\right)$ before reaching the soil surface, using a Michaelis-Menten kinetics approach that is scaled by $\phi_{\mathrm{a}}$ :

$R_{\mathrm{ox}}=\frac{\left(V_{\mathrm{max}} \times \phi_{\mathrm{a}}\right) P_{\mathrm{diff}}}{\left(K_{m}+\phi_{\mathrm{a}}\right) P_{\mathrm{diff}}} \times Q_{10 d}^{\left(T_{\mathrm{s}}-T_{d}\right) / 10}$,

where $V_{\max }$ is the maximum reaction rate and $K_{m}$ is the substrate concentration at $0.5 V_{\max }$ (van Huissteden et al., 2006). Oxidation during soil diffusion is modified by soil temperature $Q_{10}$ constraints $\left(Q_{10 d}\right) ; T_{d}$ is the reference temperature and can be defined using site-specific mean annual $T_{\mathrm{S}}$ (Le Mer and Roger, 2001). Total daily $\mathrm{CH}_{4}$ emission $\left(F_{\text {diff }}\right)$ from the soil diffusion pathway is determined by substracting $R_{\mathrm{Ox}}$ from $P_{\text {diff. }}$.

The $\mathrm{CH}_{4}$ algorithm uses a gradient-based approach to account for slow or "steady-rate" ebullition from inundated micro-sites in the landscape (Rosenberry et al., 2006; Wania et al., 2010), whereas episodic events originating deeper within the soil require more complex modeling techniques 
and input data requirements (Kettridge et al., 2011) that are beyond the scope of this study. Emission contributions due to ebullition occur when $C_{\mathrm{CH}_{4}}$ exceeds a threshold value $\left(v_{e}\right)$ of $500 \mu \mathrm{M}$ (van Huissteden et al., 2006). The magnitude of gas release is determined by steady-rate bubbling $\left(C_{e}\right)$ applied within the saturated soil pore space $\left(\varphi_{\mathrm{s}}\right)$ :

$F_{\text {ebull }}=\left(C_{e} \times \phi_{\mathrm{s}}\right)\left(C_{\mathrm{CH}_{4}}-v_{e}\right), C_{\mathrm{CH}_{4}}>v_{e}$.

\subsection{Study sites and in situ data records}

Tower EC records from six pan-Arctic peatland and tundra sites in Finland, Sweden, Russia, Greenland and Alaska were used to assess the integrated TCF model $\mathrm{CO}_{2}$ and $\mathrm{CH}_{4}$ simulations (Fig. 1; Table 1). The Scandinavian tower sites include Siikaneva (SK) in southern Finland and Stordalen Mire (SM) in northern Sweden near the Abisko Scientific Research Station. The Lena River (LR) delta site is located on Samoylov Island in northern Siberia and EC measurements from the Kytalyk (KY) flux tower were collected near Chokurdakh in northeastern Siberia. The Zackenberg (ZK) flux tower is located within the Northeast Greenland National Park, and tower data records for Alaska were obtained from a water table manipulation experiment (Zona et al., 2009; 2012; Sturtevant et al., 2012) approximately $6 \mathrm{~km}$ east of Barrow (BA). With the exception of Siikaneva, the EC tower footprints represent wet permafrost ecosystems with complex, heterogeneous terrain that includes moist depressions, drier, elevated hummocks and inundated microsites. Vegetation within the tower footprints (Rinne et al., 2007; Riutta et al., 2007; Sachs et al., 2008; Jackowicz-Korczyński et al., 2010; Parmentier et al., 2011a; Zona et al., 2011; Tagesson et al., 2012b) consists of Carex and other sedges, dwarf shrubs (e.g., Dryas and Salix), grasses (e.g., Arctagrostis) and Sphagnum moss (with the exception of Zackenberg).

Mean daily $T_{\mathrm{S}}$ and $\theta$ site measurements corresponding to near-surface $(\leq 10 \mathrm{~cm})$ soil depths were selected when possible (Table 1), to better coincide with the soil penetration depths anticipated for upcoming satellite-based microwave remote sensing missions (Kimball et al., 2012). For Siikaneva, reanalysis $\theta$ was used in place of in situ measurements as only water table depth information was available to describe soil wetness (Rinne et al., 2007). At the Lena River site $T_{\mathrm{S}}$ and $\theta(\leq 12 \mathrm{~cm})$ observations were obtained from the nearby Samoylov meteorological station and represent tundra polygon wet center, dry rim and slope conditions (Boike et al., 2008; Sachs et al., 2008). Although $\theta$ was also measured during the summer of 2006, the in situ records are limited to the wet polygon center location (Boike, personal communication, 2012) and were not used in this study due to the potential for overestimating saturated site conditions. For Zackenberg, site $T_{\mathrm{s}}$ measurements were obtained at a $2 \mathrm{~cm}$ depth (Tagesson et al., 2012a, b) within the tower footprint, while near-surface $\theta(<20 \mathrm{~cm})$ and $\geq 5 \mathrm{~cm} T_{\mathrm{s}}$ measurements were collected adjacent to the site (Sigsgaard et al., 2011). At Stordalen, site $\theta$ measurements were not avail-

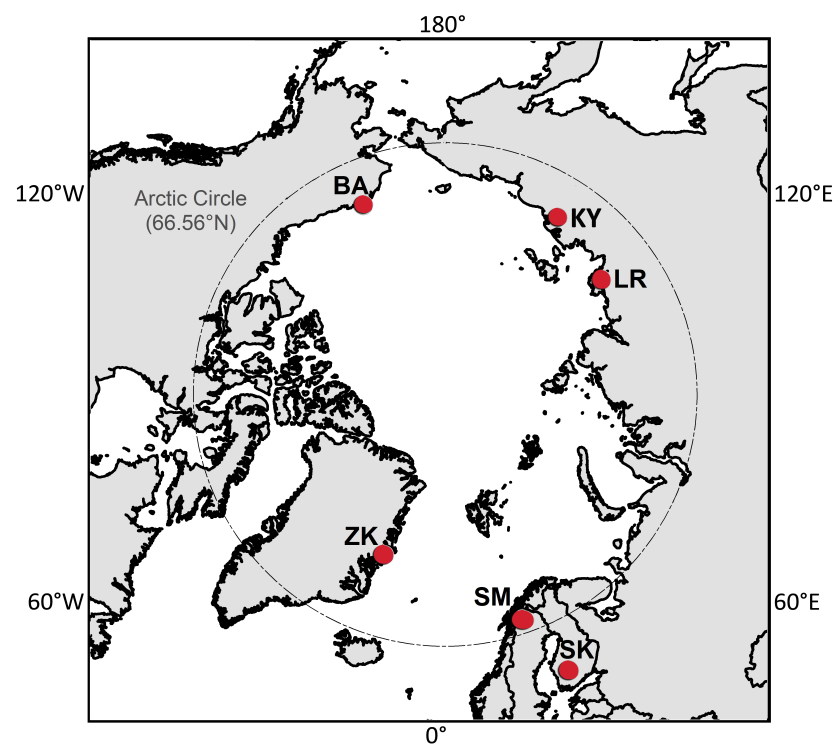

Fig. 1. Locations of the flux tower sites (circles) used in this study, including Barrow (BA), Kytalyk (KY), Lena River (LR), Siikaneva (SK), Stordalen Mire (SM) and Zackenberg (ZK). The Arctic Circle is indicated by the dashed line.

able at the time of this study (Jackowicz-Korczyński et al., 2010). Barrow (Zona et al., 2009; Sturtevant et al., 2012) includes southern (S), central (C) and northern (N) tower locations; in 2007 only $\mathrm{CO}_{2}$ and $\mathrm{CH}_{4} \mathrm{EC}$ measurements from the northern tower were used in the analysis, due to minimal EC data availability for the other tower sites following data processing (Zona et al., 2009). Many of the Barrow $\mathrm{CO}_{2}$ measurements were also rejected for the 2009 period; as a result NEE was not partitioned into $R_{\text {eco }}$ and GPP (Sturtevant et al., 2012).

\subsection{Remote sensing and reanalysis inputs}

Daily input meteorology was obtained from the Goddard Earth Observing System Data Assimilation Version 5 (GEOS-5) MERRA archive (Rienecker et al., 2011) with $1 / 2 \times 2 / 3^{\circ}$ spatial resolution. The MERRA records were recently verified for terrestrial $\mathrm{CO}_{2}$ applications in highlatitude systems (Yi et al., 2011, 2013; Yuan et al., 2011), and provide model enhanced $T_{\mathrm{s}}$ and surface $\theta$ information similar to the products planned for the NASA Soil Moisture Active Passive (SMAP) mission (Kimball et al., 2012). In addition to near-surface $(\leq 10 \mathrm{~cm}) T_{\mathrm{S}}$ and $\theta$ information from the MERRA-Land reanalysis (Reichle et al., 2011) required for the $R_{\text {eco }}$ and $\mathrm{CH}_{4}$ simulations, daily MERRA SW rad,$T_{\min }$ and VPD records were used to drive the internal GPP calculations. The MERRA near-surface $(2 \mathrm{~m})$ wind parameters were also used to obtain mean daily $\mu_{m}$ for the $\mathrm{CH}_{4}$ simulations. The MERRA-Land records for Greenland are spatially limited due to land cover/ice masking inherent in the reanalysis product, and MERRA $T_{\mathrm{S}}$ and $\theta$ were not available 
Table 1. Description of flux tower locations and site characteristics including permafrost (PF) cover and climate. The length (days) of each tower site $\mathrm{CO}_{2}$ and $\mathrm{CH}_{4}$ record is provided in addition to the observation year.

\begin{tabular}{|c|c|c|c|c|c|c|}
\hline Site name & $\begin{array}{l}\text { Location } \\
\text { (Lat. Lon.) }\end{array}$ & Climate & Land cover & Observation period & In situ data & Data source \\
\hline $\begin{array}{l}\text { Siikaneva, } \\
\text { Finland } \\
(\mathrm{SK})\end{array}$ & $\begin{array}{l}61^{\circ} 50^{\prime} \mathrm{N} \\
24^{\circ} 12^{\prime} \mathrm{E}\end{array}$ & $\begin{array}{l}\text { PF: N/A } \\
\text { MAT } 3.3^{\circ} \mathrm{C} \\
\text { MAP } 713 \mathrm{~mm}\end{array}$ & $\begin{array}{l}\text { Homogenous boreal } \\
\text { oligotrophic fen } \\
\text { with peat, sedges, } \\
\text { graminoids }\end{array}$ & $\begin{array}{l}8 \mathrm{Mar}-14 \mathrm{Nov} 2005 \\
\text { (273 days) } \mathrm{CO}_{2} \\
\text { (165 days) } \mathrm{CH}_{4}\end{array}$ & $\begin{array}{l}\mathrm{CO}_{2}, \mathrm{CH}_{4} \\
5,10 \mathrm{~cm} T_{\mathrm{s}}\end{array}$ & $\begin{array}{l}\text { Aurela et al. (2007) } \\
\text { Rinne et al. (2007) } \\
\text { Riutta et al. (2007) }\end{array}$ \\
\hline $\begin{array}{l}\text { Lena River } \\
\text { delta, } \\
\text { Russia (LR) }\end{array}$ & $\begin{array}{l}72^{\circ} 22^{\prime} \mathrm{N} \\
126^{\circ} 30^{\prime} \mathrm{E}\end{array}$ & $\begin{array}{l}\text { PF: Continuous } \\
\text { MAT }-14.7^{\circ} \mathrm{C} \\
\text { MSP } 72-208 \mathrm{~mm}\end{array}$ & $\begin{array}{l}\text { Wet polygonal } \\
\text { tundra with sedges, } \\
\text { dwarf shrubs, } \\
\text { forbes, moss }\end{array}$ & $\begin{array}{l}19 \text { Jul-21 Oct } 2003 \\
\text { (95 days) } \mathrm{CO}_{2}, \mathrm{CH}_{4} \\
9 \text { Jun-17 } \mathrm{Sep} 2006 \\
\text { (101 days) } \mathrm{CO}_{2}, \mathrm{CH}_{4}\end{array}$ & $\begin{array}{l}\mathrm{CO}_{2}, \mathrm{CH}_{4} \\
5,10 \mathrm{~cm} T_{\mathrm{S}} \\
\leq 12 \mathrm{~cm} \theta\end{array}$ & $\begin{array}{l}\text { Boike et al. (2008) } \\
\text { Kutzbach et al. (2007) } \\
\text { Sachs et al. (2008) } \\
\text { Wille et al. (2008) }\end{array}$ \\
\hline $\begin{array}{l}\text { Zackenberg, } \\
\text { Greenland } \\
\text { (ZK) }\end{array}$ & $\begin{array}{l}74^{\circ} 28^{\prime} \mathrm{N} \\
20^{\circ} 34^{\prime} \mathrm{W}\end{array}$ & $\begin{array}{l}\text { PF: Continuous } \\
\text { MAT }-9{ }^{\circ} \mathrm{C} \\
\text { MAP } 200 \mathrm{~mm}\end{array}$ & $\begin{array}{l}\text { Heterogeneous } \\
\text { wetland fen tundra } \\
\text { with graminoids, } \\
\text { heath, moss }\end{array}$ & $\begin{array}{l}24 \text { Jun-31 Oct } 2008 \\
\text { (130 days) } \mathrm{CO}_{2}, \mathrm{CH}_{4} \\
16 \text { May-25 } \mathrm{Oct}_{2009} \\
\text { (163 days) } \mathrm{CO}_{2}, \mathrm{CH}_{4}\end{array}$ & $\begin{array}{l}\mathrm{CO}_{2}, \mathrm{CH}_{4} \\
2,5,10 \mathrm{~cm} \\
T_{\mathrm{S}} \leq 20 \mathrm{~cm} \theta\end{array}$ & $\begin{array}{l}\text { Sigsgaard (2011) } \\
\text { Tagesson et al. (2012b) }\end{array}$ \\
\hline $\begin{array}{l}\text { Stordalen } \\
\text { Mire, } \\
\text { Sweden } \\
\text { (SM) }\end{array}$ & $\begin{array}{l}68^{\circ} 20^{\prime} \mathrm{N} \\
19^{\circ} 03^{\prime} \mathrm{E}\end{array}$ & $\begin{array}{l}\text { PF: Discontinuous } \\
\text { MAT }-0.9^{\circ} \mathrm{C} \\
\text { MAP } 305 \mathrm{~mm}\end{array}$ & $\begin{array}{l}\text { Palsa mire with } \\
\text { graminoids, dwarf } \\
\text { shrubs, birch, moss, } \\
\text { lichen }\end{array}$ & $\begin{array}{l}1 \text { Jan-31 Dec } 2006 \\
\text { (365 days) } \mathrm{CH}_{4} \\
1 \text { Jan-31 Dec } 2007 \\
\text { (365 days) } \mathrm{CH}_{4}\end{array}$ & $\begin{array}{l}\mathrm{CH}_{4} \\
3 \mathrm{~cm} T_{\mathrm{S}}\end{array}$ & $\begin{array}{l}\text { Jackowicz-Korczyński } \\
\text { et al. (2010) }\end{array}$ \\
\hline $\begin{array}{l}\text { Kytalyk, } \\
\text { Russia } \\
(\mathrm{KY})\end{array}$ & $\begin{array}{l}70^{\circ} 49^{\prime} \mathrm{N} \\
147^{\circ} 29^{\prime} \mathrm{E}\end{array}$ & $\begin{array}{l}\text { PF: Continuous } \\
\text { MAT }-10.5^{\circ} \mathrm{C} \\
\text { MAP } 220 \mathrm{~mm}\end{array}$ & $\begin{array}{l}\text { Polygonal tundra } \\
\text { with mixed shrub, } \\
\text { sedge, moss }\end{array}$ & $\begin{array}{l}8 \text { Jun-10 Aug } 2009 \\
\text { (64 days) } \mathrm{CO}_{2} \\
5 \text { Jul-3 Aug } 2009 \\
\text { (30 days) } \mathrm{CH}_{4}\end{array}$ & $\begin{array}{l}\mathrm{CO}_{2}, \mathrm{CH}_{4} \\
4,8 \mathrm{~cm} T_{\mathrm{S}}\end{array}$ & $\begin{array}{l}\text { Parmentier et al. } \\
(2011 a, b)\end{array}$ \\
\hline \multirow[t]{2}{*}{$\begin{array}{l}\text { Barrow, } \\
\text { Alaska } \\
\text { (BA) }\end{array}$} & $\begin{array}{l}71^{\circ} 17^{\prime} \mathrm{N} \\
156^{\circ} 35^{\prime} \mathrm{W}\end{array}$ & $\begin{array}{l}\text { PF: Continuous } \\
\text { MAT }-12{ }^{\circ} \mathrm{C} \\
\text { MAP } 106 \mathrm{~mm}\end{array}$ & $\begin{array}{l}\text { Thaw lake basin with } \\
\text { moss and sedge }\end{array}$ & $\begin{array}{l}12 \text { Jun-31 Aug } 2007 \\
\text { North: (81 days) } \mathrm{CO}_{2} \\
\text { North: (46 days) } \mathrm{CH}_{4}\end{array}$ & $\begin{array}{l}\mathrm{CO}_{2}, \mathrm{CH}_{4} \\
5,10 \mathrm{~cm} T_{\mathrm{S}} \\
\leq 10 \mathrm{~cm} \theta\end{array}$ & Zona et al. $(2009,2012)$ \\
\hline & & & & $\begin{array}{l}20 \text { Aug-21 Oct } 2009 \\
\text { North: (30, } 11 \text { days) } \mathrm{CO}_{2}, \mathrm{CH}_{4} \\
\text { Central: (12, } 23 \text { days) } \mathrm{CO}_{2}, \mathrm{CH}_{4} \\
\text { South: (2, } 10 \text { days) } \mathrm{CO}_{2}, \mathrm{CH}_{4}\end{array}$ & $\begin{array}{l}\mathrm{CO}_{2}, \mathrm{CH}_{4} \\
5 \mathrm{~cm} T_{\mathrm{S}} \\
\leq 10 \mathrm{~cm} \theta\end{array}$ & Sturtevant et al. (2012) \\
\hline
\end{tabular}

for the Zackenberg tower site. As a proxy, $T_{\mathrm{s}}$ was derived from reanalysis surface skin temperatures by applying a simple Crank-Nicholson heat diffusion scheme that accounts for energy attenuation with increasing soil depth (Wania et al., 2010); for $\theta$, records from a nearby grid cell were used to represent moisture conditions at Zackenberg.

For the daily LUE-based GPP simulations, quality screened cloud-filtered 16 day $250 \mathrm{~m}$ NDVI values from MODIS Terra (MOD13A1) and Aqua (MYD13Q1) data records (Solano et al., 2010) were used as model inputs. Differences between the MOD13A1 and MYD13Q1 retrievals were minimal at the tower locations, and the combination of Terra and Aqua MODIS records reduced the retrieval gaps to approximate 8 day intervals. The NDVI retrievals correspond to the center coordinate locations for each flux tower site, and temporal linear interpolation was used to scale the 8 day NDVI records to daily inputs. Coarser $(500-1000 \mathrm{~m}$ resolution) NDVI records were not used in this study due to the close proximity of water bodies at the tower sites, which can substantially reduce associated FPAR retrievals. In addition, $250 \mathrm{~m}$ MODIS vegetation indices have been reported to better capture the overall seasonal variability in tower EC flux records (Schubert et al., 2012).

\subsection{TCF model parameterization}

A summary of the site-specific TCF model parameters is provided in the Supplement (Table S2). Parameter values associated with grassland biomes were selected for the LUE model VPD and $T_{\min }$ modifiers used to estimate GPP (Yi et al., 2013), as more specific values for tundra and mossdominated wetlands were not available. Parameter values for $\theta_{\max }$ were obtained using growing-season maximum $\theta$ measurements for each site and $\theta_{\min }$ was set to 0.15 for scaling purposes. Model $\varepsilon_{\max }$ was specified as $0.82 \mathrm{mg} \mathrm{C} \mathrm{MJ}^{-1}$ for the duration of the growing season, although actual LUE can vary throughout the summer due to differences in vegetation growth phenology and nutrient availability (Connolly et al., 2009; King et al., 2011). The tundra CUE ranged from 0.45 to 0.55 (Choudhury, 2000); a lower CUE value of 0.35 was used for the moss-dominated Siikaneva site due to a more moderate degree of carbon assimilation occurring in bryophytes that has been observed in other sub-Arctic communities (Street et al., 2012). For the TCF model $F_{\text {met }}$ parameter, the percentage of NPP allocated to $C_{\text {met }}$ varied between $70 \%$ and $72 \%$ for tower tundra sites (Kimball et al., 2009) compared to $50 \%$ and $65 \%$ for Siikaneva and 
Stordalen, where moss cover is more abundant. The TCF model $R_{\mathrm{o}}$ parameter ranged from 4.5 and $22.4 \mu \mathrm{MCH}_{4} \mathrm{~d}^{-1}$ (Walter and Heimann, 2000; van Huissteden et al., 2006). Values for $Q_{10 p}$ varied between 3.5 and 4 due to an enhanced microbial response to temperature variability under colder climate conditions (Gedney and Cox, 2003; Inglett et al., 2012). A $Q_{10 d}$ of 2 was assigned for $\mathrm{CH}_{4}$ oxidation (Zhuang et al., 2004; van Huissteden et al., 2006). Parameter values for $P_{\text {trans }}$, which indicates relative plant transport ability, ranged from 7 to 9 (dimensionless); lower values were assigned to tower locations with a higher proportion of shrub and moss cover, whereas higher $P_{\text {trans }}$ corresponds to sites where sedges are more prevalent (Ström et al., 2005; Rinne et al., 2007). For $\lambda$, the scaled conductance for lower site wind sensitivity was used in the $\mathrm{CH}_{4}$ model simulations, except for the Lena River, which showed higher sensitivity to surface turbulence. Values for $P_{\text {ox }}$ ranged from 0.7 in tundra to 0.8 in Sphagnum-dominated systems to account for higher $\mathrm{CH}_{4}$ oxidation by peat mosses (Parmentier et al., 2011c). Due to a lack of detailed soil profile descriptions and heterogeneous tower footprints, soil porosity was assigned at $75 \%$ for sites with more abundant fibrous surface layer peat (i.e., Siikaneva and Stordalen) and $70 \%$ elsewhere to reflect more humified or mixed organic and mineral surface soils (Elberling et al., 2008; Verry et al., 2011).

\subsection{TCF model simulations}

The TCF model was first evaluated against tower EC records using simulations driven with in situ environmental data including EC-based GPP, $T_{\mathrm{s}}, \theta$ and $\mu_{m}$. This step allowed for baseline TCF model $R_{\text {eco }}$ and $\mathrm{CH}_{4}$ flux estimates to be assessed without introducing additional uncertainties from input reanalysis meteorology and LUE model derived GPP calculations. Four additional TCF model simulations were conducted using reanalysis $\theta, T_{\mathrm{s}}, \mu_{m}$ (in the $\mathrm{CH}_{4}$ module), or internal model GPP in place of the in situ data. A final TCF model run included only satellite and reanalysis-based data, and was used to establish annual GPP, $R_{\text {eco }}$ and $\mathrm{CH}_{4}$ carbon budgets for each site. Baseline carbon pools were initialized by continuously cycling ("spinning-up") the model for the tower years of record (described in Table 1) to reach a dynamic steady-state between estimated NPP and surface soil organic carbon stocks (Kimball et al., 2009). In situ data records were used during the model spin-up to establish baseline organic carbon conditions for the first five TCF model simulations, although it was often necessary to supplement these data with reanalysis information to obtain a continuous annual time series. The final model simulation did not include in situ data in the spin-up process.

The temporal agreement between the tower EC records and TCF model simulations was assessed using Pearson correlation coefficients $(r ; \pm$ one standard deviation) for the daily, 8 day, and total-period (EC length of record) cumulative carbon fluxes and corresponding tests of significance at a
0.05 probability level. The 8 day and total-period cumulative fluxes were evaluated, in addition to the daily fluxes, to account for differences between the model estimates and tower $\mathrm{EC}$ records stemming from temporal lags between changing environmental conditions and resulting carbon $\left(\mathrm{CO}_{2}, \mathrm{CH}_{4}\right)$ emissions (Lund et al., 2010; Levy et al., 2012). The mean residual error (MRE) between the tower EC records and TCF modeled $\mathrm{CO}_{2}$ and $\mathrm{CH}_{4}$ fluxes was used to identify potential positive (underestimation) and negative (overestimation) biases in the simulations; root-mean-square-error (RMSE) differences were used as a measure of model estimate uncertainty in relation to the tower EC records.

\section{Results}

\subsection{Surface organic carbon pools}

The TCF model generated surface soil organic carbon pools represent steady-state conditions obtained through the continuous cycling of in situ or satellite and reanalysis environmental data for the years of record associated with each tower site (described in Table 1). Approximately 600 and 1000 years of model spin-up were required for $C_{\text {rec }}$ to reach dynamic steady state conditions. Over $95 \%$ of the resulting total carbon pool was allocated to $C_{\text {rec }}$ by the TCF model, with 2-3\% stored as $C_{\text {met }}$ and the remainder partitioned to $C_{\text {str. }}$. The estimated carbon pools from the in situ (reanalysis-based) model spin-up ranged from approximately $3.3 \mathrm{~kg} \mathrm{C} \mathrm{m}^{-2}\left(2.3 \mathrm{~kg} \mathrm{C} \mathrm{m}^{-2}\right)$ for Zackenberg and Stordalen to $1.3 \mathrm{~kg} \mathrm{C} \mathrm{m}^{-2}\left(2.1 \mathrm{~kg} \mathrm{C} \mathrm{m}^{-2}\right)$ for the other tower sites.

Differences in carbon stocks, resulting from the use of satellite remote sensing and reanalysis information in the TCF model, reflect warm or cold biases in the input $T_{\mathrm{S}}$ records relative to the in situ data that modified the rate of $\mathrm{CO}_{2}$ loss during model initialization. The larger carbon stocks at Zackenberg, compared to the other tundra sites, resulted from higher tower EC-based GPP inputs that often exceeded $5 \mathrm{~g} \mathrm{C} \mathrm{m}^{-2} \mathrm{~d}^{-1}$ in mid-summer, and a short ( $<50$ day) peak growing season (Tagesson et al., 2012a) that minimized TCF modeled $R_{\mathrm{h}}$ losses. Although it was necessary to use internal LUE-based GPP calculations for Stordalen in the absence of available $\mathrm{CO}_{2}$ records, the resulting $C_{\text {met }}$ and $C_{\text {rec }}$ carbon stocks were similar in magnitude to surface litter measurements at this site (Olsrud and Christensen, 2011). The TCF model simulated carbon stock for Lena River was less than a $2.9 \mathrm{~kg} \mathrm{C} \mathrm{m}^{-2}$ average determined from in situ $(\leq 10 \mathrm{~cm}$ depth) measurements of nearby river terrace soils (Zubrzycki et al., 2013), but this could have resulted from site spatial heterogeneity and the use of recent climate records in the model spin-up that may not reflect past conditions. 


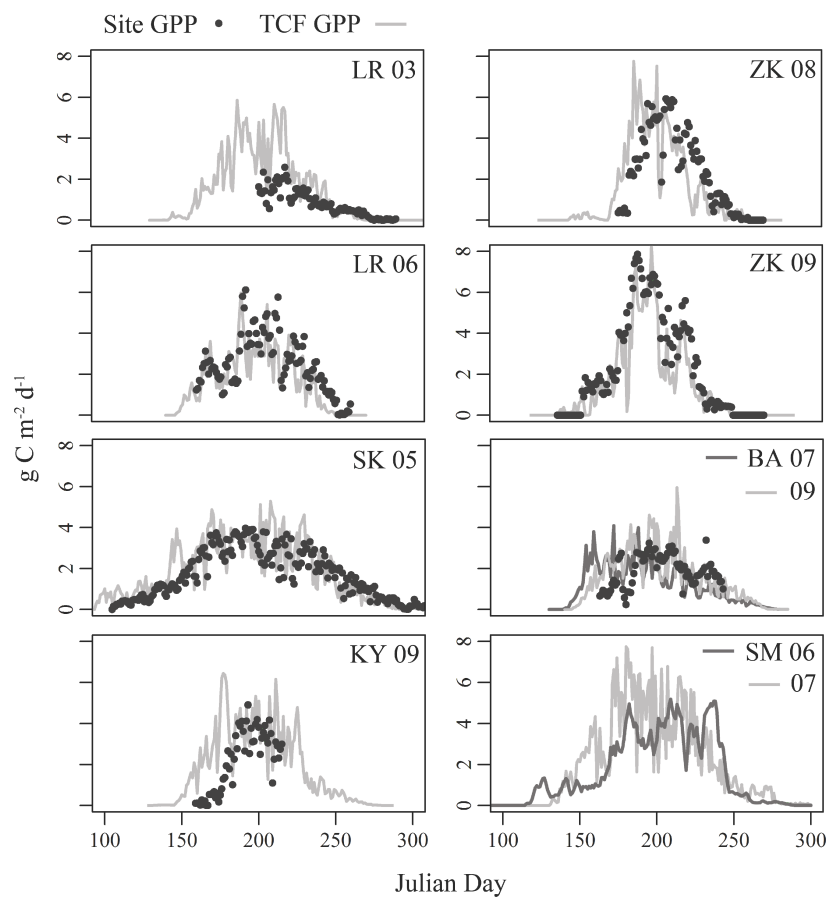

Fig. 2. TCF model simulations for GPP (lines) using input remote sensing and reanalysis information as compared with flux tower EC records (circles). Site GPP records were not available for SM and BA 2009.

\subsection{LUE-based GPP}

The GPP simulations using reanalysis and satellite-based inputs captured the overall seasonality observed in the tower records (Fig. 2; Table 2) and explained $76 \%\left(r^{2}\right.$; $p<0.05, N=7)$ of variability in the total EC period-ofrecord fluxes (Fig. 3). The across-site RMSE and MRE were $1.3 \pm 0.51$ and $-0.1 \pm 0.7 \mathrm{~g} \mathrm{C} \mathrm{m}^{-2} \mathrm{~d}^{-1}$, respectively. Although the 8 day cumulative flux correspondence between the tower EC and TCF model GPP estimates was strong $\left(r^{2}=75 \pm 16 \%\right)$, the model-tower agreement decreased considerably for daily GPP $\left(r^{2}=57 \pm 22 \%\right)$. These differences may reflect a delayed response in vegetation productivity following changes in atmospheric and soil conditions (Lund et al., 2010), and short term fluctuations in the reanalysis $\mathrm{SW}_{\text {rad }}$ inputs. For Kytalyk, the large RMSE $\left(2.2 \mathrm{~g} \mathrm{C} \mathrm{m}^{-2} \mathrm{~d}^{-1}\right)$ observed for the TCF model GPP simulations resulted from warm spring air temperatures that reduced $T_{\min }$ constraints on carbon assimilation, although a similar increase in GPP did not occur in the EC-based records. This lack of response likely resulted from a shallow $(<14 \mathrm{~cm})$ early season thaw depth at this site, that limited bud break activity in deeper rooted shrubs (e.g., Betula nana and Salix pulchra). To address this, an additional simulation was conducted using a temperature driven phenology model described in Parmentier et al. (2011a) to better inform the start of growing season in the TCF model. This step reduced the corresponding RMSE

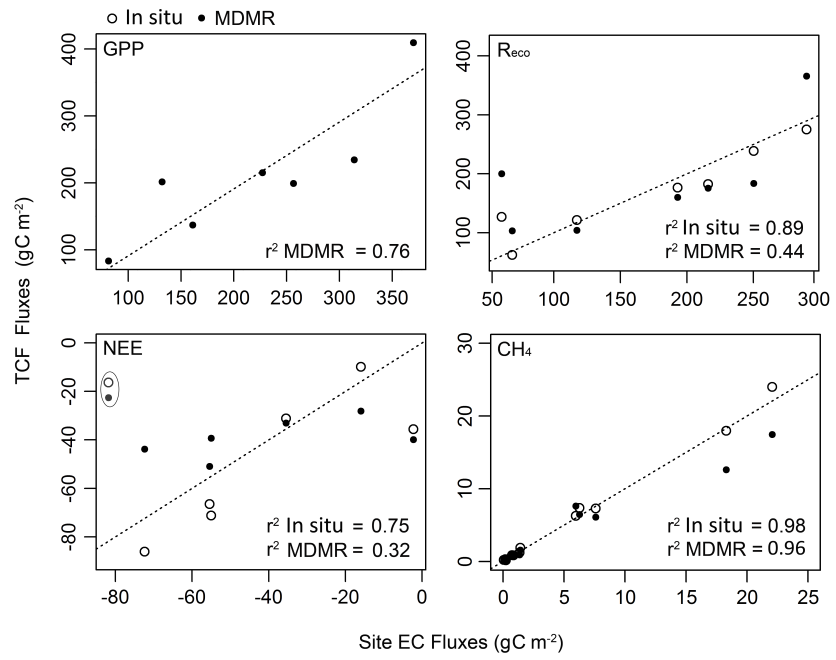

Fig. 3. Correspondence between TCF model and tower EC records for cumulative $\left(\mathrm{g} \mathrm{C} \mathrm{m}^{-2}\right) \mathrm{GPP}, R_{\mathrm{eco}}, \mathrm{NEE}$, and $\mathrm{CH}_{4}$ fluxes from six pan-Arctic tower locations. The TCF model simulations include those derived from in situ measurements (open circles) or MODIS remote sensing and MERRA reanalysis inputs (MDMR; in black). A $1: 1$ relationship is indicated by the dashed line. The $r^{2}$ agreement is significant at a 0.05 probability level, except for MDMRbased $R_{\text {eco }}$ and NEE ( $p=0.16$ and 0.27 ), and excludes NEE fluxes for $\mathrm{KY}$ (circled) due to large differences in the $\mathrm{CO}_{2}$ response relative to the other sites.

difference for Kytalyk by $56 \%$ (to $1 \mathrm{~g} \mathrm{C} \mathrm{m}^{-2} \mathrm{~d}^{-1}$ ) with an associated $r^{2}$ of $67 \%$.

Although previous LUE models (e.g., Running et al., 2004; Yi et al., 2013) have relied solely on VPD to represent water related constraints to GPP, our approach also considers soil moisture to better account for the sensitivity of bryophytes and shallow rooted vegetation to surface drying (Wu et al., 2013). Including this additional moisture constraint reduced the overall TCF model and tower GPP RMSE and MRE differences by approximately $14 \%$ and $92 \%$. However, the model simulations continued to overestimate GPP fluxes for Siikaneva, Lena River (2003), and Kytalyk $\left(\mathrm{MRE}=-0.6 \pm 0.8 \mathrm{~g} \mathrm{C} \mathrm{m}^{-2} \mathrm{~d}^{-1}\right.$ ). This residual GPP bias could be influenced by inconsistencies between the coarse-scale MERRA reanalysis inputs and local tower meteorology, as reported elsewhere (e.g., Yi et al., 2013), although systematic biases for the high-latitude regions have not been identified. For instance, periods of warmer ( 3 to $4^{\circ} \mathrm{C}$ ) reanalysis $T_{\min }$ inputs relative to in situ measurements at Lena River in 2003 led to seasonally higher TCF modeled GPP fluxes. In contrast, the reanalysis $T_{\min }$ at Barrow was 2 to $7^{\circ} \mathrm{C}$ cooler in mid-summer than the local meteorology; this resulted in significantly lower $(p<0.05)$ TCF model GPP estimates relative to the tower EC records (Table 2). It is also possible that differences in the light response curve and respiration models, used when partitioning the site EC NEE fluxes into GPP and $R_{\text {eco }}$ (i.e., Aurela et al., 2007; 
Table 2. Tower EC $\mathrm{CO}_{2}$ records and TCF modeled gross primary production (GPP), ecosystem respiration $\left(R_{\mathrm{eco}}\right)$ and net ecosystem exchange (NEE) derived using in situ information (in parentheses) or satellite remote sensing and reanalysis inputs. The Pearson correlation coefficients $(r)$ are significant at a 0.05 probability level, excluding Kytalyk 2009 NEE $(r \leq 0.11, p \geq 0.17)$ and Barrow 2007N GPP and $\operatorname{NEE}(r<0.1, p \geq 0.16)$.

\begin{tabular}{|c|c|c|c|c|c|c|c|c|}
\hline \multirow[t]{2}{*}{ Site } & \multirow[t]{2}{*}{ Year } & \multirow[t]{2}{*}{ Flux } & \multirow[t]{2}{*}{$r$} & \multirow[t]{2}{*}{8 day $r$} & RMSE & MRE & Site EC & TCF Model \\
\hline & & & & & \multicolumn{2}{|c|}{$\mathrm{g} \mathrm{C} \mathrm{m}^{-2} \mathrm{~d}^{-1}$} & \multicolumn{2}{|c|}{ Cumulative ( $\mathrm{g} \mathrm{C} \mathrm{m}^{-2}$ ) } \\
\hline \multirow[t]{3}{*}{ Siikaneva } & 2005 & GPP & 0.84 & 0.94 & 0.8 & -0.2 & 361.1 & 409.4 \\
\hline & & $R_{\mathrm{eco}}$ & $0.96(0.96)$ & $0.96(0.98)$ & $0.4(0.3)$ & $-0.3(0.1)$ & 289.9 & $365.6(274.9)$ \\
\hline & & NEE & $0.49(0.91)$ & $0.92(0.92)$ & $0.5(0.3)$ & $0.3(-0.1)$ & -71.2 & $-43.8(-86.2)$ \\
\hline \multirow[t]{6}{*}{ Lena River } & 2003 & GPP & 0.74 & 0.91 & 0.7 & -0.1 & 72.3 & 131.5 \\
\hline & & $R_{\mathrm{eco}}$ & $0.77(0.87)$ & $0.83(0.91)$ & 1. $(0.3)$ & $-0.5(-0.1)$ & 56.3 & $103.3(62.4)$ \\
\hline & & NEE & $0.90(0.94)$ & $0.93(0.97)$ & $0.3(0.3)$ & $-0.1(0.1)$ & -16.0 & $-28.2(-9.9)$ \\
\hline & 2006 & GPP & 0.78 & 0.86 & 1.1 & 0.5 & 247.4 & 199.3 \\
\hline & & $R_{\mathrm{eco}}$ & $0.76(0.84)$ & $0.91(0.91)$ & $0.7(0.6)$ & $0.3(0.2)$ & 193.0 & $160(176.4)$ \\
\hline & & NEE & $0.57(0.76)$ & $0.62(0.89)$ & $0.7(0.6)$ & $0.2(-0.2)$ & -54.4 & $-39.3(-71.0)$ \\
\hline \multirow[t]{6}{*}{ Zackenberg } & 2008 & GPP & 0.75 & 0.76 & 1.8 & $<0.1$ & 218.2 & 215.4 \\
\hline & & $R_{\mathrm{eco}}$ & $0.67(0.44)$ & $0.80(0.50)$ & $1.1(1.3)$ & $0.3(0.3)$ & 215.9 & $175.5(182.6)$ \\
\hline & & NEE & $0.31(0.83)$ & $0.37(0.85)$ & $1.7(1.3)$ & $-0.3(-0.3)$ & -2.3 & $-39.9(-35.6)$ \\
\hline & 2009 & GPP & 0.91 & 0.96 & 1.3 & 0.6 & 305.0 & 234.6 \\
\hline & & $R_{\mathrm{eco}}$ & $0.86(0.90)$ & $0.93(0.96)$ & $0.8(1)$ & $0.4(0.1)$ & 250.3 & $183.7(238.6)$ \\
\hline & & NEE & $0.89(0.89)$ & $0.92(0.92)$ & $1.2(1)$ & $0.2(-0.1)$ & -54.7 & $-50.9(-66.4)$ \\
\hline \multirow[t]{3}{*}{ Kytalyk } & 2009 & GPP & 0.41 & 0.73 & 2.2 & -1.5 & 143.2 & 224.9 \\
\hline & & $R_{\mathrm{eco}}$ & $0.49(0.60)$ & $0.80(0.94)$ & $1.6(1.3)$ & $-2.2(-1.5)$ & 60.8 & $200.2(126.9)$ \\
\hline & & NEE & $0.11(0.92)$ & $0.01(0.95)$ & $1.6(1.3)$ & $0.9(1.5)$ & -82.4 & $-24.7(-16.3)$ \\
\hline \multirow[t]{5}{*}{ Barrow } & $2007 N$ & GPP & 0.12 & 0.32 & 1.1 & 0.2 & 152.0 & 137.0 \\
\hline & & $R_{\text {eco }}$ & $0.23(0.61)$ & $0.64(0.82)$ & $0.5(0.4)$ & $0.4(-0.1)$ & 117.4 & $104.3(121.6)$ \\
\hline & & NEE & $0.10(0.79)$ & $0.20(0.79)$ & $0.8(0.4)$ & $<0.1(0.1)$ & -34.6 & $-32.7(-30.4)$ \\
\hline & $2009 \mathrm{~N}$ & NEE & - & - & 1.6 & 1.4 & -62.1 & -15.6 \\
\hline & $2009 C$ & NEE & - & - & 0.5 & 0.4 & -8.3 & -3.6 \\
\hline
\end{tabular}

Kutzbach et al., 2007; Parmentier et al., 2011a; Tagesson et al., 2012a; Zona et al., 2012), may have contributed to differences between the TCF model simulations and tower $\mathrm{CO}_{2}$ records. However, further investigation is needed to determine the expected range of GPP and $R_{\text {eco }}$ that might result from variability in the flux partitioning routines.

\section{3 $R_{\text {eco }}$ and NEE}

The in situ TCF model $R_{\text {eco }}$ simulations accounted for $59 \pm 28 \%$ and $76 \pm 24 \%\left(r^{2}\right)$ of the observed variability in the respective daily and 8 day cumulative tower EC fluxes (Fig. 4; Table 2). As with GPP, the $r^{2}$ agreement increased to $89 \%(p<0.05, N=6)$ when considering the total-period cumulative fluxes (Fig. 3). The overall RMSE difference for the in situ based TCF model $R_{\text {eco }}$ and NEE simulations was $0.74 \pm 0.45 \mathrm{~g} \mathrm{C} \mathrm{m}^{-2} \mathrm{~d}^{-1}$ when using $5 \mathrm{~cm}$ depth $T_{\mathrm{S}}$ inputs. A corresponding across-site MRE of $-2.1 \pm 5.7 \mathrm{~g} \mathrm{C} \mathrm{m}^{-2} \mathrm{~d}^{-1}$ indicated that the TCF model simulations overestimated $R_{\text {eco }}$ relative to the tower records, and slightly underestimated NEE (MRE $=0.1 \pm 0.4 \mathrm{~g} \mathrm{C} \mathrm{m}^{-2} \mathrm{~d}^{-1}$ ). We also conducted TCF model simulations using $8-10 \mathrm{~cm}$ depth in situ
$T_{\mathrm{s}}$ inputs, instead of those from $\leq 5 \mathrm{~cm}$ (as reported in Table 2), to investigate the influence of deeper soil thermal controls on site $R_{\text {eco }}$ response; this step reduced the overall RMSE by approximately $12 \%$.

Incorporating the TCF internal LUE model GPP estimates increased the overall RMSE for $R_{\text {eco }}$ and NEE by $23 \%$ relative to the in situ based simulations, compared to a respective $3 \%$ and $14 \%$ increase when using reanalysis $\theta$ or $T_{\mathrm{s}}$ inputs (Fig. 5). The model-tower daily and 8 day cumulative correspondence was also lower $\left(r^{2}=32\right.$ and $56 \%$, respectively) for $\mathrm{CO}_{2}$ simulations driven using internally derived GPP, relative to those using reanalysis $\theta$ or $T_{\mathrm{S}}$ inputs $\left(r^{2}=57\right.$ and $72 \%$ ) in place of the in situ records. Without the in situ inputs, the respective RMSE and MRE difference between the reanalysis-based $R_{\text {eco }}$ (NEE) simulations and the tower EC records averaged $0.9 \pm 0.4$ and $-0.2 \pm 0.9 \mathrm{~g} \mathrm{C} \mathrm{m}^{-2} \mathrm{~d}^{-1}$ $\left(1 \pm 0.5\right.$ and $\left.0.3 \pm 0.05 \mathrm{~g} \mathrm{C} \mathrm{m}^{-2} \mathrm{~d}^{-1}\right)$

Correspondingly, the reanalysis and remote sensing-based TCF model $R_{\text {eco }}$ (NEE) simulations accounted for $51 \pm 29$ $(45 \pm 34) \%$ and $71 \pm 17(62 \pm 34) \%$ of the observed $r^{2}$ variability in the respective daily and 8 day tower EC records. The mean $r^{2}$ values exclude TCF model results for Barrow 


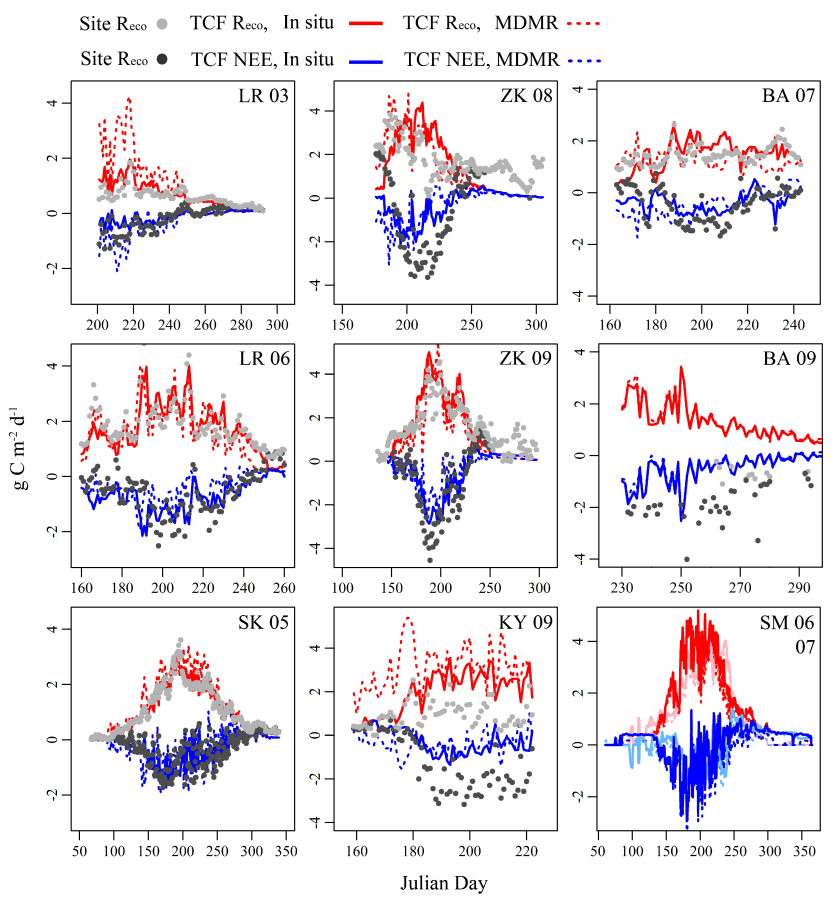

Fig. 4. TCF model $\mathrm{CO}_{2}$ simulations driven using in situ (solid lines) or remote sensing and reanalysis inputs (MDMR; dashed lines), as compared with tower EC records (circles) for $R_{\text {eco }}$ and NEE. For BA 2009, in situ $R_{\text {eco }}$ was not available and NEE measurements from the northern (central) tower are shown in black (gray). The TCF model $R_{\text {eco }}$ results for SM 2006 (2007) are displayed in light (dark) red and NEE is indicated in light (dark) blue.

and Kytalyk, which did not show significant $(r \leq 0.20$; $p \geq 0.16$ ) agreement with the site EC records (Table 2). For Barrow, it is likely that the water table manipulations at this site led to local temperature and moisture variability that was not reflected in the coarse reanalysis and remote sensing inputs. The minimal agreement at Kytalyk is attributed to higher $R_{\mathrm{h}}$ losses driven by warmer reanalysis $T_{\mathrm{S}}$ inputs, and increased $R_{\mathrm{a}}$ contributions due to the overestimation of GPP relative to the tower EC records.

\section{$3.4 \mathrm{CH}_{4}$ fluxes}

The in situ TCF model $\mathrm{CH}_{4}$ simulations explained $64 \pm 11 \%$ and $80 \pm 12 \%\left(r^{2}\right)$ of the respective daily and 8 day cumulative variability observed in the tower EC records (Fig. 6; Table 3), when excluding Kytalyk ( $p=0.1$ ). The $r^{2}$ correspondence increased to $98 \%$ when considering the total periodof-record emissions across the six sites (Fig. 3; $p<0.05$, $N=9$ ). At Kytalyk, Parmentier et al. (2011b) reported large differences in measured half-hourly $\mathrm{CH}_{4}$ fluxes following shifts in wind direction, and larger emissions from portions of the tower footprint containing Carex sp., E. angustifolium and inundated microsites. Although this may have contributed to the observed discrepancy between the TCF

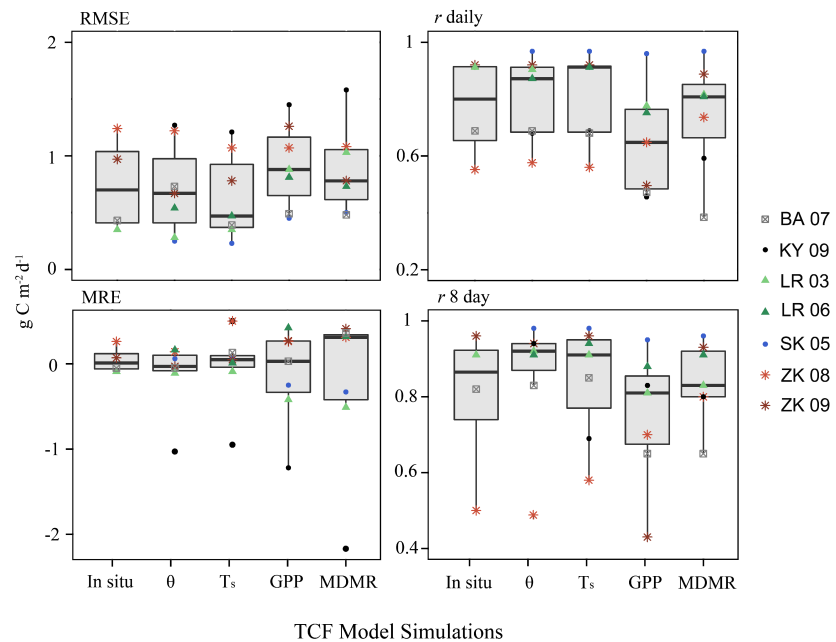

Fig. 5. TCF model accuracy for $R_{\text {eco }}$ relative to $\mathrm{CO}_{2}$ records from five tower EC sites. The TCF model simulations include those determined from in situ measurement inputs; reanalysis soil moisture $(\theta)$, soil temperature $\left(T_{\mathrm{S}}\right)$ or TCF LUE model simulated GPP inputs; TCF simulations derived entirely from remote sensing and reanalysis (MDMR) inputs. Measures of comparison include RMSE, MRE, $r$ values for daily and 8 day cumulative fluxes. The BA 2009 results represent the local spatial mean determined from north, central and southern Barrow tower locations.

model estimates and tower EC record, attempts to systematically screen the $\mathrm{CH}_{4}$ observations based on wind direction, or to use daily EC medians instead of mean values, did not substantially improve the model results.

On average, the in situ TCF model simulations overestimated $\mathrm{CH}_{4}$ fluxes relative to the tower EC records $\left(\mathrm{MRE}=-2.2 \mathrm{mg} \mathrm{C} \mathrm{m}^{-2} \mathrm{~d}^{-1}\right)$, with RMSE differences varying from 6.7 to $42.5 \mathrm{mg} \mathrm{C} \mathrm{m}^{-2} \mathrm{~d}^{-1}$. Without including $\mu_{m}$ in the TCF model, the resulting RMSE increased by $>10 \%$ and the mean daily correspondence decreased to $r^{2}<40 \%$. The most substantial difference was observed for Lena River, where excluding $\mu_{m}$ reduced the daily and 8 day emission correspondence by over $60 \%$. Unlike the TCF model $R_{\text {eco }}$ results, deeper $\left(10 \mathrm{~cm}\right.$ depth) $T_{\mathrm{s}}$ measurement inputs did not improve the RMSE values, except for Barrow $(2007 \mathrm{~N})$ where the RMSE decreased by $35 \%$. This sensitivity to deeper $T_{\mathrm{S}}$ conditions may reflect changes in active layer depth following water table manipulations at this site (Zona et al., 2009, 2012), and associated changes in carbon substrate availability. In contrast, the RMSE for Lena River was $15 \%$ higher when using in situ $10 \mathrm{~cm} T_{\mathrm{s}}$ records in the TCF model simulations instead of $5 \mathrm{~cm}$ depth measurements. A $6 \%$ decrease in the RMSE occurred for Zackenberg (2008) when using the warmer $\left(3\right.$ to $\left.5{ }^{\circ} \mathrm{C}\right) 2 \mathrm{~cm}$ depth $T_{\mathrm{s}}$ records, relative to model simulations using $5 \mathrm{~cm} T_{\mathrm{S}}$ inputs. Contrary to expectations, the $2 \mathrm{~cm}$ depth $T_{\mathrm{S}}$ inputs did not improve RMSE differences for Zackenberg in 2009 when site moisture conditions were drier (Tagesson et al., 2012a). 
Table 3. Tower $\mathrm{EC} \mathrm{CH}_{4}$ records and TCF model results using in situ information (in parentheses) or satellite remote sensing and reanalysis inputs. The Pearson correlation coefficients $(r)$ are significant at a 0.05 probability level, excluding Kytalyk $2009(r \leq 0.28, p \geq 0.07)$.

\begin{tabular}{|c|c|c|c|c|c|c|c|}
\hline \multirow[t]{2}{*}{ Site } & \multirow[t]{2}{*}{ Year } & \multirow[t]{2}{*}{$r$} & \multirow[t]{2}{*}{8 day $r$} & RMSE & MRE & Site EC & TCF model \\
\hline & & & & \multicolumn{2}{|c|}{$\mathrm{mg} \mathrm{C} \mathrm{m}^{-2} \mathrm{~d}^{-1}$} & \multicolumn{2}{|c|}{ Cumulative $\left(\mathrm{mg} \mathrm{C} \mathrm{m}^{-2}\right)$} \\
\hline Siikaneva & 2005 & $0.72(0.75)$ & $0.90(0.90)$ & $21.8(16.9)$ & $-9.6(-1.2)$ & 5.9 & $7.6(6.3)$ \\
\hline \multirow[t]{2}{*}{ Lena River } & 2003 & $0.59(0.87)$ & $0.88(0.97)$ & $9.1(7.5)$ & $4.7(0.5)$ & 1.4 & $0.9(1.2)$ \\
\hline & 2006 & $0.53(0.69)$ & $0.81(0.78)$ & $6.9(9.3)$ & $-1.3(-4.4)$ & 1.4 & $1.6(1.9)$ \\
\hline \multirow[t]{2}{*}{ Zackenberg } & 2008 & $0.78(0.84)$ & $0.91(0.95)$ & $35.7(28.5)$ & $11.6(2.4)$ & 7.6 & $6.1(7.3)$ \\
\hline & 2009 & $0.75(0.88)$ & $0.84(0.95)$ & $28.7(21.2)$ & $-1.1(-6.7)$ & 6.3 & $6.5(7.4)$ \\
\hline \multirow[t]{2}{*}{ Stordalen } & 2006 & $0.80(0.80)$ & $0.88(0.89)$ & $35(33.4)$ & $13.3(0.9)$ & 18.3 & $12.6(17.9)$ \\
\hline & 2007 & $0.80(0.79)$ & $0.94(0.89)$ & $39.4(42.5)$ & $12.6(-5.3)$ & 22.1 & $17.5(23.9)$ \\
\hline Kytalyk & 2009 & $0.28(0.24)$ & $0.66(0.41)$ & $20.1(14.9)$ & $-6.4(0.7)$ & 0.9 & $1.1(0.8)$ \\
\hline \multirow[t]{4}{*}{ Barrow } & $2007 N$ & $0.51(0.78)$ & $0.94(0.80)$ & $5.8(6.7)$ & $-1.5(-2.4)$ & 0.7 & $0.8(0.9)$ \\
\hline & $2009 N$ & - & - & $4.5(15.9)$ & $-0.5(-12.6)$ & 0.1 & $0.1(0.2)$ \\
\hline & $2009 \mathrm{C}$ & - & - & $4.2(10.2)$ & $0.4(-4.7)$ & 0.2 & $0.3(0.3)$ \\
\hline & $2009 S$ & - & - & $7.2(7.6)$ & $-0.2(6.3)$ & 0.2 & $0.2(0.2)$ \\
\hline
\end{tabular}
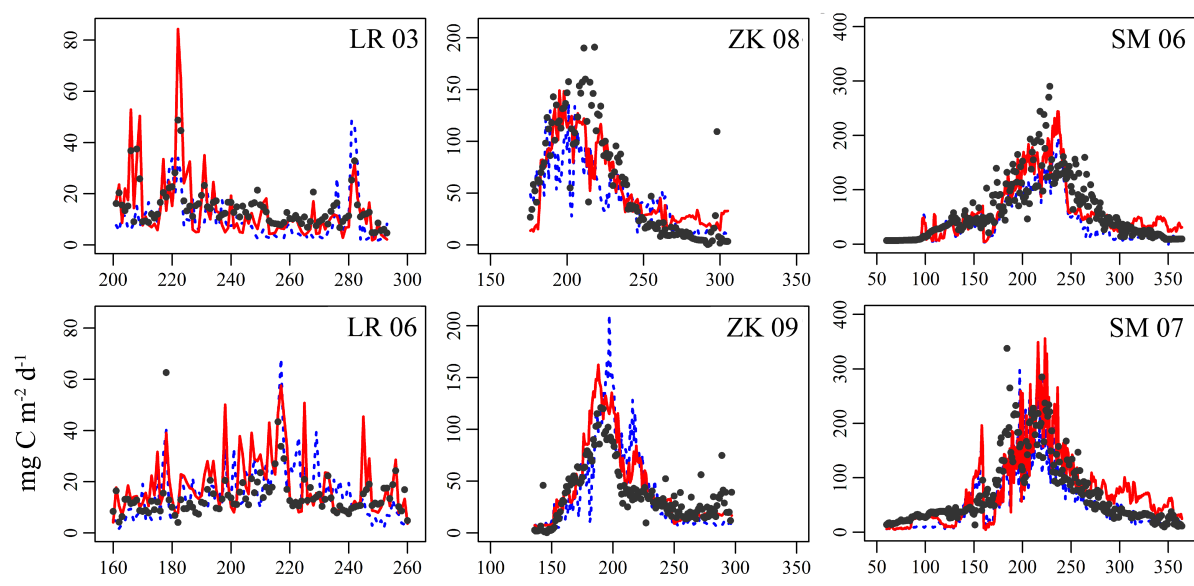

Site $\mathrm{CH}_{4}$

$\mathrm{TCF} \mathrm{CH}_{4}$, In situ

TCF $\mathrm{CH}_{4}, \mathrm{MDMR}$....
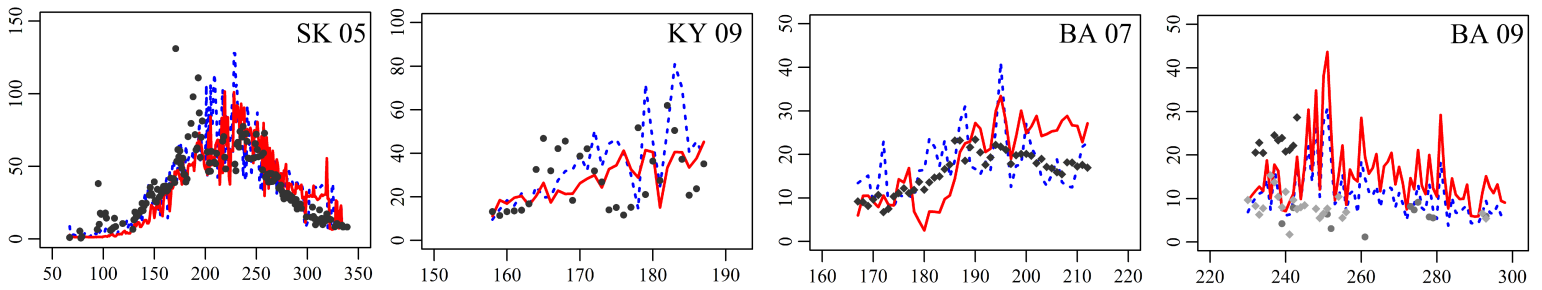

Julian Day

Fig. 6. TCF model $\mathrm{CH}_{4}$ simulations driven using in situ (solid lines) or input remote sensing and reanalysis (dashed lines) inputs, as compared with tower EC records (circles). For BA 2009, the TCF model results are simulation means for the three Barrow tower sites; diamond shapes indicate $\mathrm{CH}_{4}$ flux observations from the northern (in dark gray) and central (in light gray) towers, whereas gray circles indicate observations from the southern tower.

The reanalysis driven TCF model $\mathrm{CH}_{4}$ simulations (Fig. 6; Table 3) accounted for $48 \pm 16 \%$ and $79 \pm 8 \%\left(r^{2}\right)$ of the respective daily and 8 day variability in the tower EC records when excluding the less favorable results for Kytalyk ( $r^{2}=8$ and $44 \%$, respectively). Although slightly lower than the in situ TCF model $\mathrm{CH}_{4}$ estimates, the coarser reanalysis and remote sensing driven simulations explained $96 \%\left(r^{2}\right)$ of the total period-of-record emissions at these sites (Fig. 3). The corresponding model RMSE was $18.2 \pm 13.6 \mathrm{mg} \mathrm{C} \mathrm{m}^{-2} \mathrm{~d}^{-1}$, with an associated MRE 
difference of $1.8 \pm 7.3 \mathrm{mg} \mathrm{C} \mathrm{m}^{-2} \mathrm{~d}^{-1}$ that indicated the slight model underestimation of daily $\mathrm{CH}_{4}$ emissions. The model RMSE differences increased by approximately $15 \%$ when using reanalysis $\mu_{m}$ records or internal GPP estimates in place of the in situ inputs, and by $10 \%$ when incorporating reanalysis $T_{\mathrm{S}}$ and $\theta$ inputs (Fig. 7).

\subsection{Estimates of annual carbon budgets}

The reanalysis and remote sensing driven TCF model simulations indicated a net $\mathrm{CO}_{2}$ sink $\left(\mathrm{NEE}=-34.5 \pm 18.5 \mathrm{~g} \mathrm{C} \mathrm{m}^{-2} \mathrm{yr}^{-1}\right)$ for the tower sites, excluding Barrow in $2009\left(\mathrm{NEE}=7.3 \mathrm{~g} \mathrm{C} \mathrm{m}^{-2} \mathrm{yr}^{-1}\right)$ where the estimated $R_{\text {eco }}$ emissions exceeded annual GPP (Fig. 8). Other studies near Barrow have also reported NEE losses from wet tundra communities, resulting from drier microscale surface conditions and warming within the hummocky landscape (Huemmrich et al., 2010b; Sturtevant and Oechel, 2013 ) that can strongly influence $R_{\text {eco }}$. The corresponding TCF model $R_{\text {eco }}$ estimates ranged from 133 (Zackenberg in 2009) to $494 \mathrm{~g} \mathrm{C} \mathrm{m}^{-2} \mathrm{yr}^{-1}$ (Stordalen in 2006) with lower $\mathrm{CO}_{2}$ emissions occurring in the colder, more northern tundra sites. The strongest NEE carbon sink indicated by the model simulations was observed for the peat-rich Siikaneva site $\left(-70.3 \mathrm{~g} \mathrm{C} \mathrm{m}^{-2} \mathrm{yr}^{-1}\right)$ due to high annual GPP ( $\left.462.5 \mathrm{~g} \mathrm{C} \mathrm{m}^{-2} \mathrm{yr}^{-1}\right)$ relative to the other tower locations. Although tower $\mathrm{EC} \mathrm{CO}_{2}$ records were not available for Stordalen to verify the TCF model NEE results $(-50.8$ and $-65.8 \mathrm{~g} \mathrm{C} \mathrm{m}^{-2} \mathrm{yr}^{-1}$, respectively), the estimates are slightly smaller $\left(\sim 30 \mathrm{~g} \mathrm{C} \mathrm{m}^{-2} \mathrm{~d}^{-1}\right)$ than other NEE approximations over the same time period (Christensen et al., 2012), but are similar to observations reported for other years at this site (Olefeldt et al., 2012; Marushchak et al., 2013).

The annual TCF model $\mathrm{CH}_{4}$ estimates determined using the reanalysis inputs averaged $6.9( \pm 5.5) \mathrm{g} \mathrm{C} \mathrm{m}^{-2} \mathrm{yr}^{-1}$ for the six tower sites. The highest $\mathrm{CH}_{4}$ emissions were observed for Stordalen and Siikaneva $\left(\geq 11.8 \mathrm{~g} \mathrm{C} \mathrm{m}^{-2} \mathrm{yr}^{-1}\right)$ due to higher model-defined $\mathrm{CH}_{4}$ production rates and summer reanalysis $T_{\mathrm{s}}$ records that were often $5^{\circ} \mathrm{C}$ warmer than the other sites. In contrast, model $\mathrm{CH}_{4}$ emissions were lowest for Barrow $\left(1.8 \mathrm{~g} \mathrm{C} \mathrm{m}^{-2} \mathrm{yr}^{-1}\right)$ due to smaller GPP estimates and colder summer reanalysis $T_{\mathrm{S}}$ records that did not reflect the unusually warm site conditions in 2007 (Shiklomanov et al., 2010). The annual TCF model $\mathrm{CH}_{4}$ emissions for Lena River were relatively small $\left(2.3 \mathrm{~g} \mathrm{C} \mathrm{m}^{-2}\right.$ $\mathrm{yr}^{-1}$, on average), but are similar in magnitude to site $\mathrm{CH}_{4}$ estimates determined using more complex coupled biogeochemical and permafrost models (i.e., Zhang et al., 2012b). Although the TCF modeled $\mathrm{CH}_{4}$ fluxes contributed only $1-5 \%$ of annual carbon emissions $\left(R_{\text {eco }}+\mathrm{CH}_{4}\right)$ at the tower sites, which is similar to previous reports (Schneider von Deimling et al., 2012), these $\mathrm{CH}_{4}$ emissions reduced the NECB $\left(-23.3 \pm 19.6 \mathrm{~g} \mathrm{C} \mathrm{m}^{-2} \mathrm{yr}^{-1}\right)$ by approximately $23 \%$ relative to NEE. The annual model estimates indicated that the site $\mathrm{CO}_{2}$ and $\mathrm{CH}_{4}$ fluxes, excluding Bar-

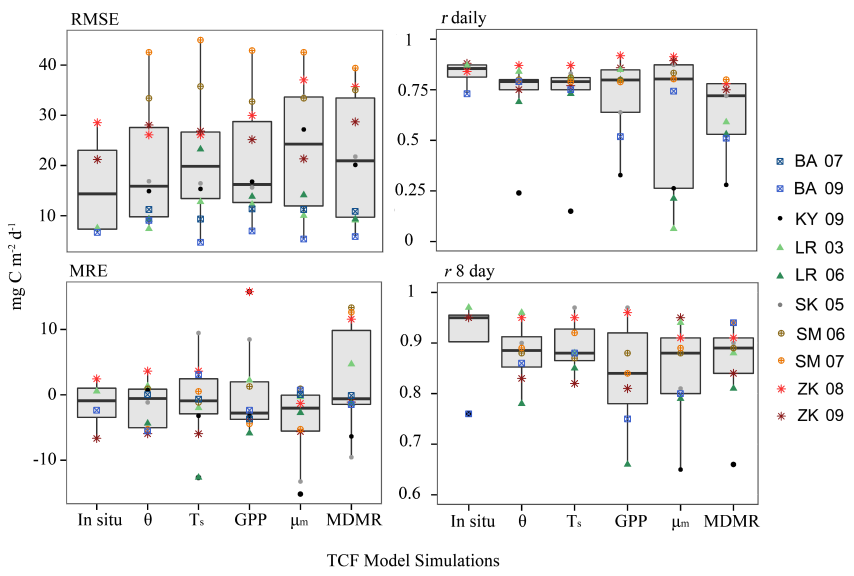

Fig. 7. TCF model accuracy relative to $\mathrm{CH}_{4}$ records from six tower EC sites. Model simulations include those derived from in situ measurements; reanalysis soil moisture $(\theta)$, soil temperature $\left(T_{\mathrm{S}}\right)$, surface wind velocity $\left(\mu_{m}\right)$ or TCF LUE model simulated GPP inputs; TCF simulations derived solely from remote sensing and reanalysis (MDMR) inputs. Measures of comparison include RMSE, MRE, $r$ values for daily and 8 day cumulative fluxes. Results for BA 2009 are means for north, central and southern Barrow tower locations.

row and Lena River, contributed to a net global warming potential (GWP) of $188 \pm 68 \mathrm{~g} \mathrm{CO}_{2} \mathrm{eq} \mathrm{m}^{-2} \mathrm{yr}^{-1}$ over a 100 year time horizon (Boucher et al., 2009) with total GWP influences by $\mathrm{CH}_{4}$ at approximately 9 to $44 \%$ that of $R_{\text {eco }}$. Similarly, the Lena River and Barrow sites mitigated GWP at a mean rate of $-40 \mathrm{~g} \mathrm{CO}_{2} \mathrm{eq} \mathrm{m}^{-2} \mathrm{yr}^{-1}$ in 2006 and 2007, but were net GWP contributors in 2003 and 2009 (25 and $160 \mathrm{~g} \mathrm{CO}_{2} \mathrm{eq} \mathrm{m}^{-2} \mathrm{yr}^{-1}$, respectively). Although site $\mathrm{CO}_{2}$ contributions from methantrophy during plant transport and soil diffusion were estimated to range from 3.8 to $58.3 \mathrm{~g} \mathrm{C} \mathrm{m}^{-2} \mathrm{yr}^{-1}$, these contributions represented $<14 \%$ of total TCF model derived $R_{\text {eco }}$.

\section{Discussion and conclusions}

The level of complexity in biophysical process models has increased considerably in recent years but there remain large differences in carbon flux estimates for northern highlatitude ecosystems (McGuire et al., 2012; Wania et al., 2013). An integrated TCF model $\mathrm{CO}_{2}$ and $\mathrm{CH}_{4}$ framework was developed to improve carbon model compatibility with remote sensing retrievals that can be used to inform changes in surface conditions across northern peatland and tundra regions. Although the TCF model lacks the biophysical and hydrologic complexity found in more sophisticated process models (e.g., Zhuang et al., 2004; Wania et al., 2010), it avoids the need for extensive parameterization by instead employing generalized surface vegetation growth, temperature, and moisture constraints on ecosystem $\mathrm{CO}_{2}$ and $\mathrm{CH}_{4}$ fluxes. Despite the relatively simple 


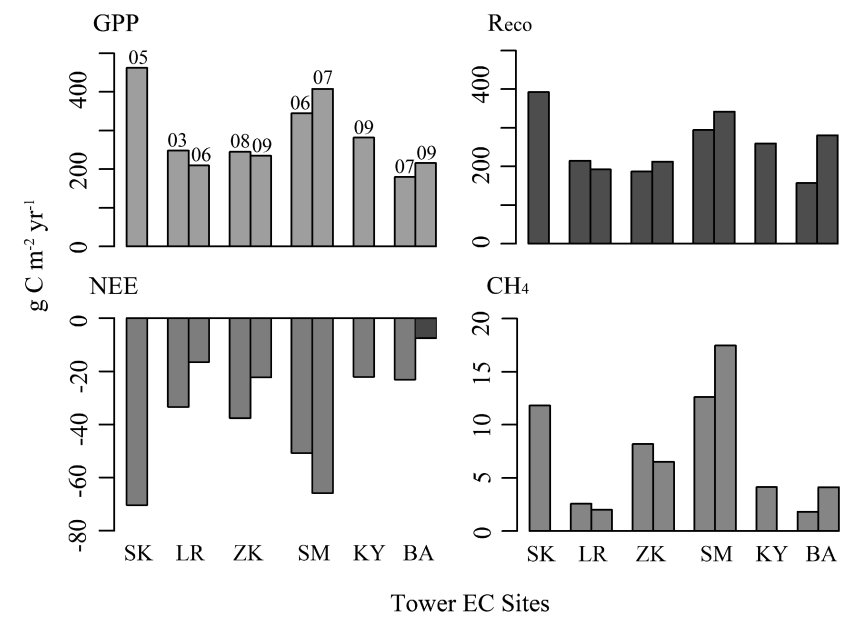

Fig. 8. The TCF model simulation results for cumulative annual GPP, $R_{\text {eco }}$, NEE and $\mathrm{CH}_{4}$ fluxes determined using satellite remote sensing and reanalysis inputs. For NEE, all sites are net $\mathrm{CO}_{2}$ sinks except for BA 2009, which is a carbon source (in black).

model approach and landscape heterogeneity at the tower sites, the TCF model simulations derived from local tower inputs captured the overall seasonality and magnitude of $R_{\text {eco }}$ and $\mathrm{CH}_{4}$ fluxes observed in the tower EC records. Overall the $R_{\text {eco }}$, NEE and $\mathrm{CH}_{4}$ emission simulations determined using local site inputs showed strong mean correspondence ( 8 day $r>0.80 ; p<0.05$ ) with tower EC records, but the strength of agreement varied considerably for the daily fluxes due to temporal lags between changing environmental conditions and carbon emissions (Zhang et al., 2012b), and larger EC measurement uncertainty at the daily time step (Baldocchi et al., 2008; Yi et al., 2013). The respective RMSE differences from the in situ TCF model $\mathrm{CO}_{2}$ and $\mathrm{CH}_{4}$ simulations averaged $0.7 \pm 0.4 \mathrm{~g} \mathrm{C} \mathrm{m}^{-2} \mathrm{~d}^{-1}$ and $17.9 \pm 11.5 \mathrm{mg} \mathrm{C} \mathrm{m}^{-2} \mathrm{~d}^{-1}$, which is comparable to other site-based model results (e.g., Marushchak et al., 2013; Sturtevant and Oechel, 2013).

In this study, we used near-surface $T_{\mathrm{S}}$ records in the model simulations to better coincide with the soil depths represented by upcoming satellite remote sensing missions, but acknowledge that deeper $T_{\mathrm{s}}$ controls are also important for regulating high-latitude carbon emissions. This was evident in TCF model $R_{\text {eco }}$ results where RMSE differences between the in situ based simulations and tower EC fluxes generally improved when using deeper $10 \mathrm{~cm} T_{\mathrm{S}}$ inputs instead of those from shallower $(\leq 5 \mathrm{~cm})$ soil depths. However, the TCF model $\mathrm{CH}_{4}$ simulations were more favorable when using near-surface ( 2 to $5 \mathrm{~cm}$ ) $T_{\mathrm{S}}$ inputs. The observed $\mathrm{CH}_{4}$ emission sensitivity to surface soil warming may be influenced by cold temperature constraints on $\mathrm{CH}_{4}$ production in the carbon-rich root zone where organic acids are more abundant (Turetsky et al., 2008; Olefeldt et al., 2013). Lightweight carbon fractions have been shown to be more suscep- tible to mineralization following soil thaw and temperature changes than heavier, more recalcitrant soil organic carbon pools in high-latitude environments (Glanville et al., 2012). However, the depletion of older organic carbon stocks may also become more prevalent in permafrost soils subject to thawing and physiochemical destabilization (Schuur et al., 2009; Hicks Pries et al., 2013a) in the absence of wet, anoxic conditions (Hugelius et al., 2012; Hicks Pries et al., 2013b). Seasonal changes in $T_{\mathrm{S}}$ constraints were also evident in this study, especially in the Zackenberg records where the TCF model underestimated tower $R_{\text {eco }}$ and $\mathrm{CH}_{4}$ emissions in autumn by not accounting for warmer temperatures deeper in the active layer that can sustain microbial activity following surface freezing (Aurela et al., 2002). Allowing the TCF model vegetation CUE parameter to change over the growing season instead of allocating $R_{\mathrm{a}}$ as a static fraction of GPP may also improve model and tower $R_{\text {eco }}$ agreement. In Arctic tundra, $R_{\mathrm{a}}$ can contribute anywhere from 40 to $70 \%$ of $R_{\mathrm{eco}}$, with higher maintenance and growth respiration occurring later in the growing season when root systems expand deeper into the soil active layer (Hicks Pries et al., 2013a). Representing $R_{\mathrm{a}}$ as a fixed proportion of daily GPP in the TCF model, and not accounting for the use of stored plant carbon reserves, may also have contributed to the lower $R_{\text {eco }}$ estimates during spring and autumn transitional periods when photosynthesis is reduced.

Our estimates of peatland and tundra $\mathrm{CO}_{2}$ fluxes using TCF model simulations driven by MERRA reanalysis and satellite (MODIS) remote sensing inputs showed favorable agreement relative to the tower EC observations, with relatively moderate RMSE uncertainties of $1.3 \pm 0.5$ (GPP), $0.9 \pm 0.4\left(R_{\text {eco }}\right)$ and $1 \pm 0.5(\mathrm{NEE}) \mathrm{g} \mathrm{C} \mathrm{m}^{-2} \mathrm{~d}^{-1}$. These model accuracies are similar to those reported in a previous TCF model analysis for the northern regions (Yi et al., 2013), and other Arctic LUE-based GPP studies (Tagesson et al., 2012a; McCallum et al., 2013). The associated modeltower RMSE for $\mathrm{CH}_{4}$ was $18.2 \pm 13.6 \mathrm{mg} \mathrm{C} \mathrm{m}^{-2} \mathrm{~d}^{-1}$, and is comparable to results from previous remote sensing driven $\mathrm{CH}_{4}$ analyses (Meng et al., 2012; Tagesson et al., 2013). The larger observed differences between TCF model and tower EC-based GPP results may reflect seasonal changes in nutrient availability (Lund et al., 2010), although one peatland study reported that nutrient limitations to plant productivity could be detected indirectly by MODIS NDVI retrievals (Schubert et al., 2010b). It is more likely that this reduced correspondence resulted from fluctuations in the reanalysis $\mathrm{SW}_{\text {rad }}$ inputs (Yi et al., 2011) and uncertainty associated with satellite NDVI and resulting FPAR inputs stemming from residual snow cover and surface water effects on optical-IR reflectances (Delbart et al., 2005). High-latitude studies have reported difficulty in using satellite NDVI to determine the start of spring bud burst and seasonal variability in leaf development (Huemmrich et al., 2010a). Evaluating other portions of the visible spectrum, including blue and green reflectances, in addition to NDVI has helped to alleviate this 
problem in remote sensing applications (Marushchak et al., 2013) and should be considered in subsequent studies. Incorporating phenological constraints into the TCF LUE model may also better characterize early season GPP, especially for plant communities such as $E$. vaginatum that are sensitive to changes in active layer depth (Parmentier et al., 2011a; Natali et al., 2012). Considering $T_{\mathrm{s}}$ as an additional constraint in the TCF LUE model may also better account for autumn GPP activity under frozen air temperatures if plant-available moisture is still available within the root zone (Christiansen et al., 2012). Yi et al. (2013) attempted to address this condition by incorporating satellite passive microwave-based freeze/thaw records $(37 \mathrm{GHz}$ ) to constrain GPP according to frozen, transitional, or non-frozen surface moisture states but did not report a significant improvement, likely due to the coarse $(25 \mathrm{~km})$ resolution freeze/thaw retrievals.

The TCF model assessment of annual NECB for the six northern tower $\mathrm{EC}$ sites indicate that $\mathrm{CH}_{4}$ emissions reduced the terrestrial net carbon sink by $23 \%$ relative to NEE. Although GPP at the Lena River and Barrow sites mitigated GWP additions from $R_{\text {eco }}$ and $\mathrm{CH}_{4}$ in two of the years examined, in most years the tower sites were GWP contributors by approximately $165 \pm 128 \mathrm{~g} \mathrm{CO}_{2} \mathrm{eq} \mathrm{m}^{-2} \mathrm{yr}^{-1}$ when considering the impact of $\mathrm{CH}_{4}$ on atmospheric forcing over a 100 year time span. These results are consistent with other model-based analyses of Arctic carbon fluxes (McGuire et al., 2010) and emphasize the importance of evaluating $\mathrm{CO}_{2}$ and $\mathrm{CH}_{4}$ emissions simultaneously when quantifying the terrestrial carbon balance and GWP for northern peatland and tundra ecosystems (Christensen et al., 2012; Olefeldt et al., 2012). However, ongoing efforts are needed to better inform landscape-scale spatial/temporal variability in soil moisture, temperature and vegetation controls on $\mathrm{CO}_{2}$ and $\mathrm{CH}_{4}$ fluxes for future model assessments using a combined network of in situ soil measurements and strategically placed EC tower sites (Sturtevant and Oechel, 2013), and regional airborne surveys. The upcoming SMAP mission may also help to determine landscape soil moisture and thermal constraints on northern carbon fluxes through relatively fine-scale $(3 \mathrm{~km}$ resolution) and lower frequency $(\leq 1.4 \mathrm{GHz})$ microwave retrievals with enhanced soil sensitivity (Entekhabi et al., 2010; Kimball et al., 2012), complimented by recent improvements in Arctic-specific reanalysis data (Bromwich et al., 2010). These advances, in conjunction with a suitable model framework to quantify ecosystem NEE and $\mathrm{CH}_{4}$ emissions, provide the means for regional carbon assessments and monitoring of the net ecosystem carbon budget and underlying environmental constraints.

\section{Supplementary material related to this article is available online at http://www.biogeosciences.net/11/ 1961/2014/bg-11-1961-2014-supplement.pdf.}

Acknowledgements. Financial support for this study was provided by the NASA Terrestrial Ecology and Science Terra and Aqua programs (NNX09AP52G, NNX11AD46G) and the NESSF program (NNX13AM92H) with work performed at the University of Montana under contract to the National Aeronautics and Space Administration. Additional support was also provided by the National Science Foundation ARC (1204263), and the Helmholtz Association (Helmholtz Young Investigators Group, grant VHNG-821). J. Rinne also acknowledges financial support from the Academy of Finland (125238).

Edited by: P. Stoy

\section{References}

Alstad, K. P. and Whiticar, M. J.: Carbon and hydrogen isotope ratio characterization of methane dynamics for Fluxnet Peatland Ecosystems, Org. Geochem., 42, 548-558, 2011.

Aurela, M., Laurila, T., and Tuovinen, J.: Annual $\mathrm{CO}_{2}$ balance of a subarctic fen in northern Europe: importance of wintertime efflux, J. Geophys. Res., 107, 4607, doi:10.1029/2002JD002055, 2002.

Aurela, M., Riutta, T., Laurila, T. Tuovinen, J.-P., Vesala, T., Tuittila, E.-S., Rinne, J., Haapanala, S., and Laine, J.: $\mathrm{CO}_{2}$ exchange of a sedge fen in southern Finland-the impact of a drought period, Tellus B, 59, 826-837, 2007.

Badawy, B., Rödenbeck, C., Reichstein, M., Carvalhais, N., and Heimann, M.: Technical Note: The Simple Diagnostic Photosynthesis and Respiration Model (SDPRM), Biogeosciences, 10, 6485-6508, doi:10.5194/bg-10-6485-2013, 2013.

Baldocchi, D.: "Breathing" of the terrestrial biosphere: lessons learned from a global network of carbon dioxide flux measurement systems, Aust. J. Bot., 56, 1-26, 2008.

Beck, P. S. A. and Goetz, S. J.: Satellite observations of high northern latitude vegetation productivity changes between 1982 2008: ecological variability and regional differences, Environ. Res. Lett., 6, 045501, doi:10.1088/1748-9326/6/4/045501, 2011.

Boike, J., Wille, C., and Abnizova, A.: Climatology and summer energy and water balance of polygonal tundra in the Lena River Delta, Siberia, J. Geophys. Res., 113, G03025, doi:10.1029/2007JG000540, 2008.

Boucher, O., Friedlingstein, P., Collins, B., and Shine, K. P.: The indirect global warming potential and global temperature change potential due to methane oxidation, Environ. Res. Lett., 4, 044007, doi:10.1088/1748-9326/4/4/044007, 2009.

Bromwich, D., Kuo, Y.-H., Serreze, M., Walsh, J., Bai, L. S., Barlage, M., Hines, K., and Slater, A.: Arctic system reanalysis: call for community involvement, EOS T. Am. Geophys. Un., 91, 1314, 2010.

Chanton, J. P.: The effect of gas transport on the isotope signature of methane in wetlands, Org. Geochem., 36, 753-768, 2005.

Choudhury, B. J.: Carbon use efficiency, and net primary productivity of terrestrial vegetation, Adv. Space Res., 26, 1105-1108, 2000.

Christensen, T. R., Jackowicz-Korczyński, M., Aurela, M., Crill, P., Heliasz, M., Mastepanov, M., and Friborg, T.: Monitoring the multi-year carbon balance of a subarctic palsa mire with micrometeorological techniques, AMBIO, 41, 207-217, 2012. 
Christiansen, C. T., Schmidt, N. M., and Michelsen, A.: High Arctic dry heath $\mathrm{CO}_{2}$ exchange during the early cold season, Ecosystems, 15, 1083-1092, doi:10.1007/s10021-012-9569-4, 2012.

Clark, D. B., Mercado, L. M., Sitch, S., Jones, C. D., Gedney, N., Best, M. J., Pryor, M., Rooney, G. G., Essery, R. L. H., Blyth, E., Boucher, O., Harding, R. J., Huntingford, C., and Cox, P. M.: The Joint UK Land Environment Simulator (JULES), model description - Part 2: Carbon fluxes and vegetation dynamics, Geosci. Model Dev., 4, 701-722, doi:10.5194/gmd-4-701-2011, 2011.

Connolly, J., Roulet, N. T., Seaquist, J. W., Holden, N. M., Lafleur, P. M., Humphreys, E. R., Heumann, B. W., and Ward, S. M.: Using MODIS derived fPAR with ground based flux tower measurements to derive the light use efficiency for two Canadian peatlands, Biogeosciences, 6, 225-234, doi:10.5194/bg-6-225-2009, 2009.

Corbett, J. E., Tfaily, M. M., Burdige, D. J., Cooper, W. T., Glaser, P. H. and Chanton, J. P.: Partitioning pathways of $\mathrm{CO}_{2}$ production in peatlands with stable carbon isotopes, Biogeochemistry, 114, 327-340, doi:10.1007/s10533-012-9813-1, 2013.

Davidson, E. A. and Janssens, I. A.: Temperature sensitivity of soil carbon decomposition and feedbacks to climate change, Nature, 440, 165-173, 2006.

Delbart, N., Kergoat, L., Le Toan, T., Lhermitte, J., and Ghislain, P.: Determination of phenological dates in boreal regions using normalized difference water index, Remote Sens. Environ., 97, 26-38, doi:10.1016/j.rse.2005.03.011, 2005.

Dijkstra, F. A., Prior, S. A., Runion, G. B., Torbert, H. A., Tian, H., Lu, C., and Venterea, R. T.: Effects of elevated carbon dioxide and increased temperature on methane and nitrous oxide fluxes: evidence from field experiments, Front. Ecol. Environ., 10, 520$527,2012$.

Dlugokencky, E. J., Bruhwiler, L., White, J. W. C., Emmons, L. K., Novelli, P. C., Montzka, S. A., Masarie, K. A., Lang, P. M., Crotwell, A. M., Miller, J. B., and Gatti, L. V.: Observational constraints on recent increases in the atmospheric $\mathrm{CH}_{4}$ burden, Geophys. Res. Lett., 36, L18803, doi:10.1029/2009GL039780, 2009.

Dolman, A. J., van der Werf, G. R., van der Molen, M. K., Ganssen, G., Erisman, J.-W., and Strengers, B.: A carbon cycle science uptake since IPCC AR-4, AMBIO, 39, 402-412, 2010.

Dorrepaal, E., Toet, S., van Logtestijn, R. S. P., Swart, E., van de Weg, M. J., Callaghan, T. V., and Aerts, R.: Carbon respiration from subsurface peat accelerated by climate warming in the subarctic, Nature, 460, 616-619, 2009.

Elberling, B., Tamstorf, M. P., Michelsen, A., Arndal, M. F., Sigsgaard, C., Illeris, L., Bay, C., Hansen, B. U., Christensen, T. R., Hansen, E. S., Jakobsen, B. H., and Beyens, L.: Soil and plant community-characteristics and dynamics at Zackenberg, Adv. Ecol. Res., 40, 223-248, 2008.

Elberling, B., Askaer, L., Jørgensen, C. J., Joensen, H. P., Kühl, M., Glud, R. N., and Lauritsen, F. R.: Linking Soil $\mathrm{O}_{2}, \mathrm{CO}_{2}$, and $\mathrm{CH}_{4}$ concentrations in a wetland soil: implications for $\mathrm{CO}_{2}$ and $\mathrm{CH}_{4}$ fluxes, Environ. Sci. Technol., 45, 3393-3399, 2011.

Elmendorf, S. C., Henry, G. H. R., Hollister, R. D., Björk, R. G., Bjorkman, A. D., Callaghan, T. V., Collier, L. S., Cooper, E. J., Cornelissen, J. H. C., Day, T. A., Fosaa, A. M., Gould, W. A., Grétarsdóttir, J., Harte, J., Hermanutz, L., Hik, D. S., Hofgaard, A., Jarrad, F., Jónsdóttir, I. S., Keuper, F., Klanderud, K., Klein, J. A., Koh, S., Kudo, G., Lang, S. I., Loewen, V., May, J.
L., Mercado, J., Michelsen, A., Molau, U., Myers-Smith, I. H., Oberbauer, S. F., Pieper, S., Post, E., Rixen, C., Robinson, C. H., Schmidt, N. M., Shaver, G. R., Stenström, A., Tolvanen, A., Totland, Ø., Troxler, T., Wahren, C.-H., Webber, P. J., Welker, J. M., and Wookey, P. A.: Global assessment of experimental climate warming on tundra vegetation: heterogeneity over space and time, Ecol. Lett., 15, 164-175, 2012.

Entekhabi, D., Njoku, E. G., O’Neill, P. E., Kellogg, K. H., Crow, W. T., Edelstein, W. N., Entin, J. K., Goodman, S. D., Jackson, T. J., Johnson, J., Kimball, J. S., Piepmeier, J. R., Koster, R. D., Martin, N., McDonald, K. C., Moghaddam, M., Moran, S., Reichle, R., Shi, J.-C., Spencer, M. W., Thurman, S. W., Tsang, L., and Van Zyl, J.: The Soil Moisture Active Passive (SMAP) mission, Proc. IEEE, 98, 704-716, 2010.

Forbrich, I., Kutzbach, L., Wille, C., Becker, T., Wu, J., and Wilmking, M.: Cross-evaluation of measurements of peatland methane emissions on microform and ecosystem scales using high- resolution landcover classification and source weight modeling, Agr. Forest Meterol., 151, 864-874, 2011.

Frenzel, P. and Rudolph, J.: Methane emission from a wetland plant: the role of $\mathrm{CH}_{4}$ oxidation in Eriophorum, Plant Soil, 202, 27-32, 1998.

Gedney, N. and Cox, P. M.: The sensitivity of global climate model simulations to the representation of soil moisture heterogeneity, J. Hydrometeorol., 4, 1265-1275, 2003.

Glanville, H. C., Hill, P. W., Maccarone, L. D., Golyshin, P. N., Murphy, D. V., and Jones, D. L.: Temperature and soil water controls on vegetation emergence, microbial dynamics, and soil carbon and nitrogen fluxes in a high Arctic tundra ecosystem, Funct. Ecol., 26, 1366-1380, 2012.

Grosse, W., Armstrong, J., and Armstrong, W.: A history of pressurized gas-flow studies in plants, Aquat. Biol., 54, 57-100, 1996.

Hargreaves, K. J., Fowler, D., Pitcairn, C. E. R., and Aurela, M.: Annual methane emission from Finnish mires estimated from eddy covariance campaign measurements, Theor. Appl. Climatol., 70, 203-213, 2001.

Hicks Pries, C. E., Schuur, E. A. G., and Crummer, K. G.: Thawing permafrost increases old soil and autotrophic respiration in tundra: partitioning ecosystem respiration using $\delta^{13} \mathrm{C}$ and $\Delta^{14} \mathrm{C}$, Glob. Change Biol., 19, 649-661, 2013a.

Hicks Pries, C. E., Schuur, E. A. G., Vogel, J. G., and Natali, S. M.: Moisture drives surface decomposition in thawing tundra, J. Geophys. Res.-Biogeo., 118, 1133-1143, doi:10.1002/jgrg.20089, 2013b.

Högström, U.: Non-dimensional wind and temperature profiles in the atmospheric surface layer: a re-evaluation, Bound.-Lay. Meteorol., 42, 55-78, 1988.

Hudson, J. M. G., Henry, G. H. R., and Cornwell, W. K.: Taller and larger: shifts in Arctic tundra leaf traits after 16 years of experimental warming. Glob. Change Biol., 17, 1013-1021, 2011.

Huemmrich, K. F., Gamon, J. A., Tweedie, C. E., Oberbauer, S. F., Kinoshita, G., Houston, S., Kuchy, A., Hollister, R. D., Kwon, H., Mano, M., Harazono, Y., Webber, P. J., and Oechel, W. C.: Remote sensing of tundra gross ecosystem productivity and light use efficiency under varying temperature and moisture conditions, Rem. Sens. Environ., 114, 481-489, 2010a.

Huemmrich, K. F., Kinoshita, G., Gamon, A., Houston, S., Kwon, H., and Oechel, W. C.: Tundra carbon balance under varying tem- 
perature and moisture regimes, J. Geophys. Res., 115, G00102, doi:10.1029/2009JG001237, 2010b.

Hugelius, G., Routh, J., Kuhry, P., and Crill, P.: Mapping the degree of decomposition and thaw remobilization potential of soil organic matter in discontinuous permafrost terrain, J. Geophys. Res.-Biogeo., 117, G02030, doi:10.1029/2011JG001873, 2012.

Hugelius, G., Tarnocai, C., Broll, G., Canadell, J. G., Kuhry, P., and Swanson, D. K.: The Northern Circumpolar Soil Carbon Database: spatially distributed datasets of soil coverage and soil carbon storage in the northern permafrost regions, Earth Syst. Sci. Data, 5, 3-13, doi:10.5194/essd-5-3-2013, 2013.

Inglett, K. S., Inglett, P. W., Reddy, K. R., and Osborne, T. Z.: Temperature sensitivity of greenhouse gas production in wetland soils of different vegetation, Biogeochemistry, 108, 77-90, 2012.

Ise, T. and Moorcroft, P. R.: The global-scale temperature and moisture dependencies of soil organic carbon decomposition: an analysis using a mechanistic decomposition model, Biogeochemistry, 80, 217-231, 2006.

Ise, T., Dunn, A. L., Wofsy, S. C., and Moorcroft, P. R.: High sensitivity of peat decomposition to climate change through watertable feedback, Nat. Geosci., 1, 763-766, 2008.

Jackowicz-Korczyński, M., Christensen, T. R., Bäckstrand, K., Crill, P., Friborg, T., Mastepanov, M., and Ström, L.: Annual cycle of methane emission from a subarctic peatland, J. Geophys. Res.-Biogeo., 115, G02009, doi:10.1029/2008JG000913, 2010.

Joabsson, A., Christensen, T. R., and Wallén, B.: Vascular plant controls on methane emissions from northern peatforming wetlands, Trends Ecol. Evol., 14, 385-388, 1999.

Kane, E. S.: Ecosystem carbon storage: squeezing the Arctic carbon balloon, Nat. Clim. Change, 2, 841-842, 2012.

Kettridge, N., Binley, A., Green, S. M., and Baird, A. J.: Ebullition events monitored from northern peatlands using electrical imaging, J. Geophys. Res., 116, G04004, doi:10.1029/2010JG001561, 2011.

Kim, Y., Kimball, J. S., Zhang, K., and McDonald, K. C.: Satellite detection of increasing Northern Hemisphere non-frozen seasons from 1979 to 2008: Implications for regional vegetation growth, Remote Sens. Environ., 121, 472-487, 2012.

Kimball, J. S., Jones, L. A., Zhang, K., Heinsch, F. A., McDonald, K. C., and Oechel, W. C.: A satellite approach to estimate landatmosphere $\mathrm{CO}_{2}$ exchange for boreal and Arctic biomes using MODIS and AMSR-E, IEEE T. Geosci. Remote, 47, 569-587, 2009.

Kimball, J. S., Reichle, R., McDonald, K., and Njoku, E.: Soil Moisture Active Passive (SMAP) Algorithm Theoretical Basis Document (ATBD): SMAP Level 4 Carbon Data Product (L4_C), Initial Release v. 1, Jet Propulsion Laboratory, California Institute of Technology, 73 pp., 2012.

King, D. A., Turner, D. P., and Ritts, W. D.: Parameterization of a diagnostic carbon cycle model for continental scale application, Remote Sens. Environ., 115, 1653-1664, 2011.

Kip, N., van Winden, J. F., Pan, Y., Bodrossy, L., Reichart, G. J., Smolders, A. J. P., Jetten, M. S. M., Damsté, J. S. S., and Op den Camp, H. J. M.: Global prevalence of methane oxidation by symbiotic bacteria in peat-moss ecosystems, Nat. Geosci., 3, 617-621, 2010.

Kutzbach, L., Wille, C., and Pfeiffer, E.-M.: The exchange of carbon dioxide between wet arctic tundra and the atmosphere at the
Lena River Delta, Northern Siberia, Biogeosciences, 4, 869-890, doi:10.5194/bg-4-869-2007, 2007.

Le Mer, J. and Roger, P.: Production, oxidation, emission and consumption of methane by soils: a review, Eur. J. Soil Biol., 37, 25-50, 2001.

Levy, P. E., Burden, A., Cooper, M. D., Dinsmore, K. J., Drewer, J., Evans, C., Fowler, D., Gaiawyn, J., Gray, A., Jones, S. K., Jones, T., McNamara, N. P., Mills, R., Ostle, N., Sheppard, L. J., Skiba, U., Sowerby, A., Ward, S. E., and Zieliński, P.: Methane emissions from soils: synthesis and analysis of a large UK data set, Glob. Change Biol., 18, 1657-1669, 2012.

Lloyd, J. and Taylor, J. A.: On the temperature dependence of soil respiration, Funct. Ecol., 8, 315-323, 1994.

Lund, M., Lafleur, P. M., Roulet, N. T., Lindroth, A., Christensen, T. R., Aurela, M., Chojnicki, B. H., Flanagan, L. B., Humphreys, E. R., Laurila, T., Oechel, W. C., Olejnik, J., Rinne, J., Schubert, P., and Nilsson, M. B.: Variability in exchange of $\mathrm{CO}_{2}$ across 12 northern peatland and tundra sites, Glob. Change Biol., 16, 2436-2448, 2010.

Marushchak, M. E., Kiepe, I., Biasi, C., Elsakov, V., Friborg, T., Johansson, T., Soegaard, H., Virtanen, T., and Martikainen, P. J.: Carbon dioxide balance of subarctic tundra from plot to regional scales, Biogeosciences, 10, 437-452, doi:10.5194/bg-10437-2013, 2013.

McCallum, I., Franklin, O., Moltchanova, E., Merbold, L., Schmullius, C., Shvidenko, A., Schepaschenko, D., and Fritz, S.: Improved light and temperature responses for light-useefficiency-based GPP models, Biogeosciences, 10, 6577-6590, doi:10.5194/bg-10-6577-2013, 2013.

McGuire, A. D., Hayes, D. J., Kicklighter, D. W., Manizza, M., Zhuang, Q., Chen, M., Follows, M. J., Gurney, K. R., McClelland, J. W., and Melillo, J. M.: An analysis of the carbon balance of the Arctic Basin from 1997 to 2006, Tellus B, 62, 455-474, 2010.

McGuire, A. D., Christensen, T. R., Hayes, D., Heroult, A., Euskirchen, E., Kimball, J. S., Koven, C., Lafleur, P., Miller, P. A., Oechel, W., Peylin, P., Williams, M., and Yi, Y.: An assessment of the carbon balance of Arctic tundra: comparisons among observations, process models, and atmospheric inversions, Biogeosciences, 9, 3185-3204, doi:10.5194/bg-9-3185-2012, 2012.

Meng, L., Hess, P. G. M., Mahowald, N. M., Yavitt, J. B., Riley, W. J., Subin, Z. M., Lawrence, D. M., Swenson, S. C., Jauhiainen, J., and Fuka, D. R.: Sensitivity of wetland methane emissions to model assumptions: application and model testing against site observations, Biogeosciences, 9, 2793-2819, doi:10.5194/bg-92793-2012, 2012.

Merbold, L., Kutsch, W. L., Corradi, C., Kolle, O., Rebmann, C., Stoy, P. C., Zimov, S. A., and Schulze, E.-D.: Artificial drainage and associated carbon fluxes $\left(\mathrm{CO}_{2} / \mathrm{CH}_{4}\right)$ in a tundra ecosystem, Glob. Change Biol., 15, 2599-2614, 2009.

Moosavi, S. C. and Crill, P. M.: Controls on $\mathrm{CH}_{4}$ and $\mathrm{CO}_{2}$ emissions along two moisture gradients in the Canadian boreal zone, J. Geophys. Res.-Atmos., 102, 261-277, 1997.

Natali, S. M., Schuur, E. A., and Rubin, R. L.: Increased plant productivity in Alaskan tundra as a result of experimental warming of soil and permafrost, J. Ecol., 100, 488-498, 2012.

Oberbauer, S. F., Cheng, W., Gillespie, C. T., Ostendorf, B., Sala, A., Gebauer, G., Virginia, R. A., and Tenhunen, J. D.: Landscape patterns of carbon dioxide exchange in tundra ecosystems, in: 
Ecological Studies, Vol. 120, edited by: Reynolds, J. F. and Tenhunen, J. D., Springer-Verlag Berlin, Heidelberg, 223-256, 1996.

Olefeldt, D., Roulet, N. T., Bergeron, O., Crill, P., Bäckstrand, K., and Christensen, T. R.: Net carbon accumulation of a high-latitude permafrost palsa mire similar to permafrost-free peatlands, Geophys. Res. Lett., 39, 589-603, doi:10.1029/2011GL050355, 2012.

Olefeldt, D., Turetsky, M. R., Crill, P. M., and McGuire, A. D.: Environmental and physical controls on northern terrestrial methane emissions across permafrost zones, Glob. Change Biol., 19, 589-603, 2013.

Olivas, P. C., Oberbauer, S. F., Tweedie, C. E., Oechel, W. C., and Kuchy, A.: Responses of $\mathrm{CO}_{2}$ flux components of Alaskan Coastal Plain tundra to shifts in water table, J. Geophys. Res.Biogeo., 115, G00105, doi:1029/2009JG001254, 2010.

Olsrud, M. and Christensen, T. R.: Carbon partitioning in a wet and a semiwet subarctic mire ecosystem based on in situ ${ }^{14} \mathrm{C}$ pulse labeling, Soil Biol. Biochem., 43, 231-239, 2011.

Parmentier, F. J. W., van der Molen, M. K., van Huissteden, J., Karsanaev, S. A., Kononov, A. V., Suzdalov, D. A., Maximov, T. C., and Dolman, A. J.: Longer growing seasons do not increase net carbon uptake in the northeastern Siberian tundra, J. Geophys. Res.-Biogeo., 116, G04013, doi:10.1029/2011JG001653, 2011a.

Parmentier, F. J. W., van Huissteden, J., van der Molen, M. K., Schaepman-Strub, G., Karsanaev, S. A., Maximov, T. C., and Dolman, A. J.: Spatial and temporal dynamics in eddy covariance observations of methane fluxes at a tundra site in northeastern Siberia, J. Geophys. Res.-Biogeo., 116, G03016, doi:10.1029/2010JG001637, 2011b.

Parmentier, F. J. W., van Huissteden, J., Kip, N., Op den Camp, H. J. M., Jetten, M. S. M., Maximov, T. C., and Dolman, A. J.: The role of endophytic methane-oxidizing bacteria in submerged Sphagnum in determining methane emissions of Northeastern Siberian tundra, Biogeosciences, 8, 1267-1278, doi:10.5194/bg-8-12672011, 2011c.

Parmentier, F. J. W., Christensen, T. R., Sorensen, L. L., Rysgaard, S., McGuire, A. D., Miller, P. A., and Walker, D. A.: The impact of lower sea-ice extent on Arctic greenhouse-gas exchange, Nature Clim. Change, 3, 195-202, 2013.

Peng, D., Zhang, B., and Liu, L.: Comparing spatiotemporal patterns in Eurasian FPAR derived from two NDVI-based methods, Int. J. Digital Earth, 5, 283-298, 2012.

Petrescu, A. M. R., van Beek, L. P. H., van Huissteden, J., Prigent, C., Sachs, T., Corradi, C. A. R., Parmentier, F. J. W., and Dolman, A. J.: Modeling regional to global $\mathrm{CH}_{4}$ emissions of boreal and arctic wetlands, Global Biogeochem. Cy., 24, GB4009, doi:10.1029/2009GB003610, 2010.

Porter, C. H., Jones, J. W., Adiku, S., Gijsman, A. J., Gargiulo, O., and Naab, J. B.: Modeling organic carbon and carbon-mediated soil processes in DSSAT V4.5, Oper. Res. Int. J., 10, 274-278, 2010.

Potter, C., Klooster, S., Hiatt, S., Fladeland, M., Genovese, V., and Gross, P.: Methane emissions from natural wetlands in the United States: Satellite-derived estimation based on ecosystem carbon cycling, Earth Interact., 10, 1-12, 2006.

Preuss, I., Knoblauch, C., Gebert, J., and Pfeiffer, E.-M.: Improved quantification of microbial $\mathrm{CH}_{4}$ oxidation efficiency in arctic wetland soils using carbon isotope fractionation, Biogeosciences, 10, 2539-2552, doi:10.5194/bg-10-2539-2013, 2013.

Raupach, M. R.: Influences of local feedbacks on land-air exchanges of energy and carbon, Glob. Change Biol., 4, 477-494, 1998.

Reiche, M., Gleixner, G., and Küsel, K.: Effect of peat quality on microbial greenhouse gas formation in an acidic fen, Biogeosciences, 7, 187-198, doi:10.5194/bg-7-187-2010, 2010.

Reichle, R. H., Koster, R. D., De Lannoy, G. J. M., Forman, B. A., Liu, Q., Mahanama, S. P. P., and Toure, A.: Assessment and enhancement of MERRA land surface hydrology estimates, J. Climate, 24, 6322-6338, 2011.

Rienecker, M. M., Suarez, M. J., Gelaro, R., Todling, R., Bacmeister, J., Liu, E., Bosilovich, M. G., Schubert, S. D., Takacs, L., Kim, G.-K., Bloom, S., Chen, J., Collins, D., Conaty, A., da Silva, A., Gu, W., Joiner, J., Koster, R. D., Lucchesi, R., Molod, A., Owens, T., Pawson, S., Pegion, P., Redder, C. R., Reichle, R., Robertson, F. R., Ruddick, A. G., Sienkiewicz, M., and Woollen, J.: MERRA: NASA's Modern-Era Retrospective Analysis for Research and Applications, J. Climate, 24, 3624-3648, 2011.

Riley, W. J., Subin, Z. M., Lawrence, D. M., Swenson, S. C., Torn, M. S., Meng, L., Mahowald, N. M., and Hess, P.: Barriers to predicting changes in global terrestrial methane fluxes: analyses using CLM4Me, a methane biogeochemistry model integrated in CESM, Biogeosciences, 8, 1925-1953, doi:10.5194/bg-8-19252011, 2011.

Rinne, J., Riutta, T., Pihlatie, M., Aurela, M., Haapanala, S., Tuovinen, J., Tuittila, E., and Vesala, T.: Annual cycle of methane emission from a boreal fen measured by the eddy covariance technique, Tellus B, 59, 449-457, 2007.

Riutta, T., Laine, J., Aurela, M., Rinne, J., Vesala, T., Laurila, T., Haapanala, S., Pihlatie, M., and Tuittila, E.-S.: Spatial variation in plant community functions regulates carbon gas dynamics in a boreal fen ecosystems, Tellus B, 59, 838-852, 2007.

Roberts, J.: The influence of physical and physiological characteristics of vegetation on their hydrological response, Hydrol. Process., 14, 2885-2901, 2000.

Rosenberry, D. O., Glaser, P. H., and Siegel, D. I.: The hydrology of northern peatlands as affected by biogenic gas: current developments and research needs, Hydrol. Processes, 20, 3601-3610, 2006.

Running, S. W., Nemani, R. R., Heinsch, F. A., Zhao, M., Reeves, M., and Hashimoto, H.: A continuous satellite-derived measure of global terrestrial primary production, BioScience, 54, 547$560,2004$.

Sachs, T., Wille, C., Boike, J., and Kutzbach, L.: Environmental controls on ecosystem- scale $\mathrm{CH}_{4}$ emission from polygonal tundra in the Lena River Delta, Siberia, J. Geophys. Res., 113, 30963110, doi:10.1029/2007JG000505, 2008.

Sachs, T., Giebels, M., Boike, J., and Kutzbach, L.: Environmental controls on $\mathrm{CH}_{4}$ emission from polygonal tundra on the microsite scale in the Lena river delta, Siberia, Glob. Change Biol., 16, 3096-3110, 2010.

Schneider von Deimling, T., Meinshausen, M., Levermann, A., Huber, V., Frieler, K., Lawrence, D. M., and Brovkin, V.: Estimating the near-surface permafrost-carbon feedback on global warming Biogeosciences, 9, 649-665, doi:10.5194/bg-9-649-2012, 2012. 
Schubert, P., Eklundh, L., Lund, M., and Nilsson, M.: Estimating northern peatland $\mathrm{CO}_{2}$ exchange from MODIS time series data, Remote Sens. Environ, 114, 1178-1189, 2010a.

Schubert, P., Lund, M., Ström, L., and Eklundh, L.: Impact of nutrients on peatland GPP estimations using MODIS time series, Remote Sens. Environ., 114, 2137-2145, 2010b.

Schubert, P., Lagergren, F., Aurela, M., Christensen, T., Grelle, A., Heliasz, M., Klemedtsson, L., Lindroth, A., Pilegaard, K., Vesala, T., and Eklundh, L.: Modeling GPP in the Nordic forest landscape with MODIS time series data-Comparison with the MODIS GPP product, Remote Sens. Environ., 126, 136-147, 2012.

Schuur, E. A. G., Vogel, J. G., Crummer, K. G., Lee, H., Sickman, J. O., and Osterkamp, T. E.: The effect of permafrost thaw on old carbon release and net carbon exchange from tundra, Nature, 459, 556-559, 2009.

Shiklomanov, N. I., Streletskiy, D. A., Nelson, F. E., Hollister, R. D., Romanovsky, V. E., Tweedie, C. E., Bockheim, J. G., and Brown, J.: Decadal variations of active-layer thickness in moisturecontrolled landscapes, Barrow, Alaska, J. Geophys. Res., 115, G00104, doi:10.1029/2009JG001248, 2010.

Sigsgaard, C.: Guidelines and sampling procedures for the geographical monitoring programme of Zackenberg Basic. Zackenberg Ecological Research Operations, GeoBasis, 124 pp., 2011.

Sitch, S., McGuire, A. D., Kimball, J., Gedney, N., Gamon, J., Engstrom, R., Wolf, A., Zhuang, Q., Clein, J., and McDonald, K. C.: Assessing the carbon balance of circumpolar Arctic tundra using remote sensing and process modeling, Ecol. App., 17, 213-234, 2007.

Sjögersten, S. and Wookey, P. A.: The impact of climate change on ecosystem carbon dynamics at the Scandinavian mountain birch forest-tundra heath ecotone, AMBIO, 38, 2-10, 2009.

Solano, R., Didan, D., Jacobson, A., and Huete, A.: MODIS Vegetation Index User's Guide (MOD13 Series), Version 2.0. Vegetation Index and Phenology Lab, The University of Arizona, 42 pp., 2010.

Spahni, R., Wania, R., Neef, L., van Weele, M., Pison, I., Bousquet, P., Frankenberg, C., Foster, P. N., Joos, F., Prentice, I. C., and van Velthoven, P.: Constraining global methane emissions and uptake by ecosystems, Biogeosciences, 8, 1643-1665, doi:10.5194/bg8-1643-2011, 2011.

Street, L. E., Stoy, P. C., Sommerkorn, M., Fletcher, B. J., Sloan, V. L., Hill, T. C., and Williams, M.: Seasonal bryophyte productivity in the sub-Arctic: a comparison with vascular plants, Funct. Ecol., 26, 365-378, 2012.

Ström, L., Ekberg, A., Mastepanov, M., and Christensen, T. R.: The effect of vascular plants on carbon turnover and methane emissions from a tundra wetland, Glob. Change Biol., 9, 1185-1192, 2003.

Ström, L., Mastepanov, M., and Christensen, T. R.: Species-specific effects of vascular plants on carbon turnover and methane emissions from wetlands, Biogeochemistry, 75, 65-82, 2005.

Sturtevant, C. S. and Oechel, W. C.: Spatial variation in landscapelevel $\mathrm{CO}_{2}$ and $\mathrm{CH}_{4}$ fluxes from arctic coastal tundra: influence from vegetation, wetness, and the thaw lake cycle, Glob. Change Biol., 19, 2853-2866, doi:10.1111/gbc.12247, 2013.

Sturtevant, C. S., Oechel, W. C., Zona, D., Kim, Y., and Emerson, C. E.: Soil moisture control over autumn season methane flux,
Arctic Coastal Plain of Alaska, Biogeosciences, 9, 1423-1440, doi:10.5194/bg-9-1423-2012, 2012.

Sun, X., Song, C., Guo, Y., Wang, X., Yang, G., Li, Y., Mao, R., and Lu, Y.: Effect of plants on methane emissions from a temperate marsh in different seasons, Atmos. Envion., 60, 277-282, 2012.

Tagesson, T., Mastepanov, M., Tamstorf, M. P., Eklundh, L., Schubert, P., Ekberg, A., Sigsgaard, C., Christensen, T. R., and Ström, L.: High-resolution satellite data reveal an increase in peak growing season gross primary production in a high-Arctic wet tundra ecosystem 1992-2008, Int. J. Appl. Earth Obs., 18, 407-416, 2012a.

Tagesson, T., Mölder, M., Mastepanov, M., Sigsgaard, C., Tamstorf, M. P., Lund, M., Falk, J. M., Lindroth, A., Christensen, T. R., and Ström, L.: Land-atmosphere exchange of methane from soil thawing to soil freezing in a high-Arctic wet tundra ecosystem, Glob. Change Biol., 18, 1928-1940, 2012b.

Tagesson, T., Mastepanov, M., Mölder, M., Tamstorf, M. P., Eklundh, L., Smith, B., Sigsgaard, C., Lund, M., Ekberg, A., Falk, J. M., Friborg, T., Christensen, T. R., and Ström, L.: Modelling of growing season methane fluxes in a high-Arctic wet tundra ecosystem 1997-2010 using in situ and high-resolution satellite data, Tellus B, 65, 19722, doi:10.3402/tellusb.v65i0.19722, 2013.

Tian, H., Xu, X., Liu, M., Ren, W., Zhang, C., Chen, G., and Lu, C.: Spatial and temporal patterns of $\mathrm{CH}_{4}$ and $\mathrm{N}_{2} \mathrm{O}$ fluxes in terrestrial ecosystems of North America during 1979-2008: application of a global biogeochemistry model, Biogeosciences, 7, 2673-2694, doi:10.5194/bg-7-2673-2010, 2010.

Turetsky, M. R., Treat, C. C., Waldrop, M. P., Waddington, J. M., Harden, J. W., and McGuire, D.: Short-term response of methane fluxes and methanogen activity to water table and soil warming manipulations in an Alaskan peatland, J. Geophys. Res., 113, G00A10, doi:10.1029/2007JG000496, 2008.

van Huissteden, J., van den Bos, R., and Marticorena Alvarez, I.: Modelling the effect of water-table management on $\mathrm{CO}_{2}$ and $\mathrm{CH}_{4}$ fluxes from peat soils, Neth. J. Geosci., 85, 3-18, 2006.

van Hulzen, J. B., Segers, R., van Bodegom, P. M., and Leffelaar, P. A.: Temperature effects on soil methane production: an explanation for observed variability, Soil Biol. Biochem., 31, 19191929, 1999.

Verry, E. S., Boelter, D. H., Paivanen, J., Nichols, D. S., Malterer, T., and Gafni, A.: in: Peatland Biogeochemistry and Watershed Hydrology at the Marcell Experimental Forest, edited by: Kolka, R., Sebestyen, S., Verry, E. S., and Brooks, K., CRC Press, Boca Raton, 135-176, 2011.

von Fischer, J. C., and Hedin, L. O.: Controls on soil methane fluxes: tests of biophysical mechanisms using stable isotope tracers, Global Biogeochem. Cy., 21, GB2007, doi:10.1029/2006GB002687, 2007.

von Fischer, J. C., Rhew, R. C., Ames, G. M., Fosdick, B. K., and von Fischer, P. E.: Vegetation height and other controls of spatial variability in methane emissions from the Arctic coastal tundra at Barrow, Alaska, J. Geophys. Res., 115, G00103, doi:10.1029/2009JG001283, 2010.

Wagner, D., Kobabe, S., and Liebner, S.: Bacterial community structure and carbon turnover in permafrost-affected soils of the Lena Delta, northeastern Siberia, Can. J. Microbiol., 55, 73-83, 2009 . 
Walter, B. P., and Heimann, M.: A process-based, climate-sensitive model to derive methane emissions from natural wetlands: application to five wetland sites, sensitivity to model parameters, and climate, Global Biogeochem. Cy., 14, 745-765, 2000.

Wania, R., Ross, I., and Prentice, I. C.: Implementation and evaluation of a new methane model within a dynamic global vegetation model: LPJ-WHyMe v1.3.1, Geosci. Model Dev., 3, 565-584, doi:10.5194/gmd-3-565-2010, 2010.

Wania, R., Melton, J. R., Hodson, E. L., Poulter, B., Ringeval, B., Spahni, R., Bohn, T., Avis, C. A., Chen, G., Eliseev, A. V., Hopcroft, P. O., Riley, W. J., Subin, Z. M., Tian, H., van Bodegom, P. M., Kleinen, T., Yu, Z. C., Singarayer, J. S., Zürcher, S., Lettenmaier, D. P., Beerling, D. J., Denisov, S. N., Prigent, C., Papa, F., and Kaplan, J. O.: Present state of global wetland extent and wetland methane modelling: methodology of a model inter-comparison project (WETCHIMP), Geosci. Model Dev., 6, 617-641, doi:10.5194/gmd-6-617-2013, 2013.

Watts, J. D., Kimball, J. S., Jones, L. A., Schroeder, R., and McDonald, K. C.: Satellite microwave remote sensing of contrasting surface water inundation changes within the Arctic-Boreal Region, Remote Sens. Environ., 127, 223-236, 2012.

Wegner, L. H.: Oxygen transport in waterlogged plants, in: Waterlogging Signalling and Tolerance in Plants, edited by: Mancuso, S. and Shabala, S., Springer-Verlag Berlin Heidelberg, 294 pp., 2010.

Wille, C., Kutzbach, L., Sachs, T., Wagner, D., and Pfeiffer, E. -M.: Methane emission from Siberian arctic polygonal tundra: eddy covariance measurements and modeling, Glob. Change Biol., 14, 1395-1408, 2008.

Wu, J., Roulet, N. T., Sagerfors, J., and Nilsson, M. B.: Simulation of six years of carbon fluxes for a sedge-dominated oligotrophic minerogenic peatland in Northern Sweden using the McGill wetland model (MWM), J. Geophys. Res.-Biogeo., 118, 795-807, doi:10.1002/jgrg.20045, 2013.

Yan, H., Wang, S. Q., Billesbach, D., Oechel, W., Zhang, J. H., Meyers, T., Martin, T. A., Matamala, R., Baldocchi, D., Bohrer, G., Bragoni, D., and Scott, R.: Global estimation of evapotranspiration using a leaf area index-based surface energy and water balance model, Remote Sens. Environ., 124, 581-595, 2012.

Yang, R. and Friedl, M. A.: Determination of roughness lengths for heat and momentum over boreal forests, Bound.-Lay. Meterol., 107, 581-603, 2002.

Yi, Y., Kimball, J. S., Jones, L. A., Reichle, R. H., and McDonald, K. C.: Evaluation of MERRA land surface estimates in preparation for the soil moisture active passive mission, J. Climate, 24, 3797-3816, 2011.

Yi, Y., Kimball, J. S., Jones, L. A., Reichle, R. H., Nemani, R., and Margolis, H. A.: Recent climate and fire disturbance impacts on boreal and arctic ecosystem productivity estimated using a satellite-based terrestrial carbon flux model, J. Geophys. Res.Biogeo., 118, 606-622, doi:10.1002/jgrg.20053, 2013.
Yuan, W., Luo, Y., Li, X., Liu, S., Yu, S., Zhou, T., Bahn, M., Black, A., Desai, A. R., Cescatti, A., Marcolla, B., Jacobs, C., Chen, J., Aurela, M., Bernhofer, C., Gielen, B., Bohrer, G., Cook, D. R., Dragoni, D., Dunn, A. L., Gianelle, D., Grünwald, T., Ibrom, A., Leclerc, M. Y., Lindroth, A., Liu, H., Marchesini, L. B., Montagnani, L., Pita, G., Rodeghiero, Rodrigues, A., Starr, G., and Stoy, P. C.: Redefinition and global estimation of basal ecosystem respiration rate, Global Biogeochem. Cy., 25, GB4002, doi:10.1029/2011GB004150, 2011.

Zhang, X., He, J., Zhang, J., Polyakov, I., Gerdes, R., Inoue, J., and $\mathrm{Wu}, \mathrm{P}$. : Enhanced poleward moisture transport and amplified northern high-latitude wetting trend, Nat. Clim. Change, 3, 47-51, 2012a.

Zhang, Y., Sachs, T., Li, C., and Boike, J.: Upscaling methane fluxes from closed chambers to eddy covariance based on a permafrost biogeochemistry integrated model, Glob. Change Biol., 18, 1428-1440, 2012b.

Zhao, M., Heinsch, F. A., Nemani, R. M., and Running, S. W.: Improvements of the MODIS terrestrial gross and net primary production global data set, Remote Sens. Environ., 95, 164-176, 2005.

Zhuang, Q., Melillo, J. M., Kicklighter, D. W., Prinn, R. G., McGuire, A. D., Steudler, P. A., Felzer, B. S., and Hu, S.: Methane fluxes between terrestrial ecosystems and the atmosphere at northern high latitudes during the past century: a retrospective analysis with a process-based biogeochemistry model, Global Biogeochem. Cy., 18, GB3010, doi:10.1029/2004GB002239, 2004.

Zona, D., Oechel, W. C., Kochendorfer, J., Paw U, K. T., Salyuk, A. N., Olivas, P. C., Oberbauer, S. F., and Lipson, D. A.: Methane fluxes during the initiation of a large-scale water table manipulation experiment in the Alaskan Arctic tundra, Global Biogeochem. Cy., 23, GB2013, doi:10.1029/2009GB003487, 2009.

Zona, D., Oechel, W. C., Richards, J. H., Hastings, S., Kopetz, I., Ikawa, H., and Oberbauer, S.: Light-stress avoidance mechanisms in a Sphagnum-dominated wet coastal Arctic tundra ecosystem in Alaska, Ecology, 92, 633-644, 2011.

Zona, D., Lipson, D. A., Paw U, K. T., Oberbauer, S. F., Olivas, P., Gioli, B., and Oechel, W. C.: Increased $\mathrm{CO}_{2}$ loss from vegetated drained lake tundra ecosystems due to flooding, Global Biogeochem. Cy., 26, GB2004, doi:10.1029/2011GB004037, 2012.

Zubrzycki, S., Kutzbach, L., Grosse, G., Desyatkin, A., and Pfeiffer, E.-M.: Organic carbon and total nitrogen stocks in soils of the Lena River Delta, Biogeosciences, 10, 3507-3524, doi:10.5194/bg-10-3507-2013, 2013. 